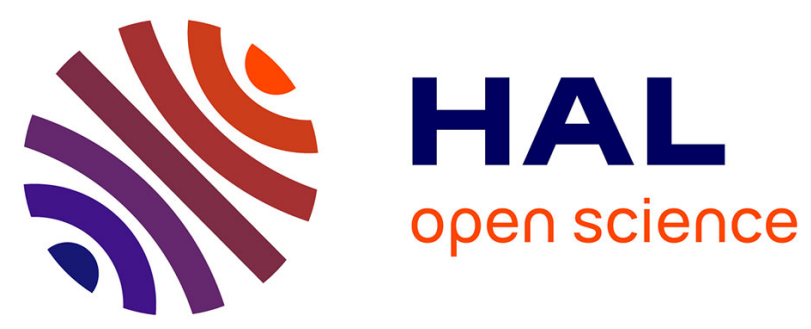

\title{
Zinc-rich clays in supergene non-sulfide zinc deposits
}

\author{
Flavien Choulet, M. Buatier, Luc Barbanson, Régis Guégan, A. Ennaciri
}

\section{To cite this version:}

Flavien Choulet, M. Buatier, Luc Barbanson, Régis Guégan, A. Ennaciri. Zinc-rich clays in supergene non-sulfide zinc deposits. Mineralium Deposita, 2016, 51 (4), pp.467-490. 10.1007/s00126-015-06188. insu-01239887

\section{HAL Id: insu-01239887 https://hal-insu.archives-ouvertes.fr/insu-01239887}

Submitted on 10 Dec 2015

HAL is a multi-disciplinary open access archive for the deposit and dissemination of scientific research documents, whether they are published or not. The documents may come from teaching and research institutions in France or abroad, or from public or private research centers.
L'archive ouverte pluridisciplinaire HAL, est destinée au dépôt et à la diffusion de documents scientifiques de niveau recherche, publiés ou non, émanant des établissements d'enseignement et de recherche français ou étrangers, des laboratoires publics ou privés.

\section{(1) (1) $\$$}

Distributed under a Creative Commons Attribution - NonCommercial - NoDerivatives 44.0 
Zinc-rich clays in supergene non-sulfide zinc deposits.

1 "Fertilization" of barren clays in supergene non-sulphide zinc deposits

2

3 Choulet F..$^{1,}$, Buatier M. ${ }^{2}$, Barbanson L. ${ }^{2}$, Guégan R. ${ }^{2}$, Ennaciri A. ${ }^{3}$

4

$5{ }^{1}$ : Chrono-Environnement, Université de Franche-Comté/CNRS (UMR6249), Besançon, France

$6 \quad$ 2: ISTO, Université d'Orléans/CNRS (UMR7327), Orléans, France

$7 \quad{ }^{3}:$ Groupe Managem, Casablanca, Morocco

$8 \quad$ ": corresponding author flavien.choulet @univ-fcomte.fr

10 Abstract

11

The nature and the origin of zinc clays are poorly understood. Based on the example of the Bou Arhous $\mathrm{Zn}-\mathrm{Pb}$ ore deposit in the Moroccan High Atlas, this study presents new advances for the characterization of barren and mineralised clays associated to zinc non-sulphide ores. In the field, white to ochre granular clays are associated with willemite, whilst red smooth clays fill karst-related cavities cutting across the non-sulphide ore bodies. Red clays (kaolinite chlorite, illite and smectite) present evidence of stratification that reflects internal sedimentation processes during karst evolution. White clays contain $7 \AA$-clay mineral/smectite irregular mixed layers with less than $20 \%$ of smectite layers.

19 The willemite crystals are partially dissolved and are surrounded by authigenic zinc clay minerals.

20 WDS analyses on newly formed clay aggregates have revealed that this mixed layered mineral is 21 composed by fraipontite and sauconite. CEC measurements support that zinc is only located within the octahedral sheets. These new results support the following process: 1) dissolution of willemite, leading

23 to releasing $\mathrm{Si}$ and $\mathrm{Zn}, 2$ ) interaction between $\mathrm{Zn}-\mathrm{Si}$ rich solutions and residual-detrital clays, 3) neogenesis of mixed-layered zinc clay minerals that grow over detrital micas, representing the source 25 for Al.

27 Keyword: supergene zinc deposits, karst, clay minerals, Morocco

\section{1) Introduction}


2011), because of their size and shape characteristics. The typical problems met by the mining industry encompass the difficulties of handling, crushing, screening, milling and classifying clay-rich raw material. High grade of clay results in poor selectivity and thus significantly slow flotation kinetics (e.g. Bayraktar et al. 1998; Fuerstenau et al. 2007). Occurrence of clays in the ore may also affect leaching techniques by increasing pulp viscosity. Despite many efforts to fathom these crucial difficulties, cost of solutions is considerable and hence clays act as a brake on ore extraction and processing. Another difficulty with clays associated to ores is their potential to trap metal (Newman 1987). Hence a noteworthy amount of economic elements is captured in clays, which are often difficult to process for recovery (e.g. Ni-rich clays, Crundwell et al. 2011). Understanding the nature and the origin of clays associated to ores is critical for designing flowsheet and identifying potential unconventional sources for critical metal extraction and recovery.

Recent development of coupled techniques of leaching, solvent extraction and electrowinning and their application to zinc smelting (Gnoinski 2006; de Wet and Singleton 2008; Abkhoshk et al. 2014) have contributed to revive interest in the disregarded non-sulphide deposits with successful application in Namibia, Peru and Morocco. Supergene non-sulphide zinc deposits are formed during weathering in relation with tectonics and climate (Hitzman et al. 2003). Such deposits are described around the world and occur in various geological environments, from silicoclastic to carbonate host rocks (Boni and Large 2003). Based on genetic processes at their origin, three types of supergene deposits have been distinguished: 1) direct-replacement deposits, 2) wall-rock deposits and 3) karst-

51 filling deposits (Hitzman et al. 2003). These different processes may occur together in a given deposit, affecting the texture of ores and providing an intricate mineralogical record. This includes carbonates (smithsonite), hydrated carbonates (hydrozincite), silicates (willemite), hydrated silicates (hemimorphite) and various rare minerals, including clays such as sauconite, a smectite containing up to $50 \%$ wt of $\mathrm{ZnO}$ (Ross 1946) or more rarely fraipontite, a zinc bertherine (Fransolet and Bourguignon 1975).

In many supergene zinc deposits, mineralised clay material represents a significant economic resource that cannot be ignored (e.g. up to $30 \%$ of the ore at Accha in Peru, Boni et al. 2009a). The occurrence of such amount of clays in the ore requires desliming and results in lower zinc recovery (de Wet and Singleton 2008), although the impact of clays is probably lower than expected from 
mineralurgical tests (Boni et al. 2009b). Besides, the ability of clays to sorb or catch $\mathrm{Zn}^{2+}$ cations located within the interlayer space of swelling clays is well known (Bradbury and Baeyens 1999;

63 Churakov and Dähn 2012), implying natural clays may represent an economic potential of zinc recovery without much efforts. Although zinc enriched clays are frequently described in supergene deposits, clear identification of the nature of clay minerals remains rare and the classical sauconite assessment is highly speculative. In addition, the origin of zinc clays and its place within the ore evolution remain badly understood. Moroccan High Atlas. This deposit is hosted in Lower Jurassic limestone, and ore is mainly willemite, whose origin is not clearly understood (Choulet et al. 2014). Willemite is associated to various types of clayey material, presenting differences in mineralogy, texture and Zn content. The Bou Arhous ore deposit represents a key natural example to understand the origin of zinc-bearing clays and their place in the ore deposition. Using microscopic observations and classical techniques for investigating clay minerals, we aim at characterizing the nature of clays recorded at Bou Arhous and debate on their origin. Further quantification of the cation exchange capacity (CEC) allows us to discuss the potential of zinc recovery.

\section{2) Geological setting of the Bou Arhous ore deposit}

The Bou Arhous $\mathrm{Pb}-\mathrm{Zn}$ ore deposit $\left(32.27^{\circ} \mathrm{N}, 3.76^{\circ} \mathrm{W}\right)$ is located in the Moroccan High Atlas range, $60 \mathrm{~km}$ to the north-east of Errachidia city (Fig. 1A). The local geology of this deposit has been extensively studied by Leblanc (1968) and recently revisited in Choulet et al. (2014). results from the far-field effect of the Alpine collision events since mid-Tertiary (ca. $40 \mathrm{Ma}$ ) and up to Pleistocene (Frizon de Lamotte et al. 2009). As a consequence, the Mesozoic sedimentary basins formed during the opening of Tethys and Atlantic Oceans have been affected by inversion tectonics accompanied by regional uplift and localized exhumation of Lower Jurassic and Triassic strata in the core of narrow anticlines. Thereafter, exhumed strata experienced surface weathering leading to the 
91 the Triassic and Lower Jurassic strata (Fig. 1B). The fold-related "Grand Accident" thrust is rooted in

92 the Triassic substratum (Figs. 1B and 1C; Teixell et al. 2003) and represents a reactivated normal fault that delimitated contrasting paleogeographic domains of the former Tethys Sea (Warme 1998). To the

94 north of the fault, deep-seated dolomitic limestone is almost barren, whereas massive limestone of the southern domain originally deposited in reef or para-reef environments includes lenses of base metal sulphides (Figs. 1B and 1C). At site of the Bou-Arhous mine located in the footwall of the "Grand Accident" thrust, the two limbs of the anticline are vertical (Fig. 2A) or slightly recumbent and the fold hinge is missing (Fig. 1C). Host rocks of mineralisation include Sinemurian black limestone, locally interbedded with thin layers of greyish marls (Fig. 2B), which have experienced slight dolomitisation during diagenesis and emplacement of base metals sulphide lenses (Leblanc 1968). In depth, mineralisation is tectonically juxtaposed along the "Grand Accident" thrust to the Triassic variegated shales associated to gypsum (Fig. 2C). Following exploration campaigns in the 1960's, the Bou Arhous mine has been exploited by

104 Managem since the early 2000's and reserves have been estimated at $250 \mathrm{kt}$ grading $4 \% \mathrm{~Pb}$ and $16 \%$ Zn. Mineralisation consists of an intricate network of various-sized veins, extending over 18000 square metres. Veins up to 10 metres in width parallel the stratification and dip steeply to the north (Fig. 2A). Non-sulphide zinc-bearing minerals include willemite, hydrozincite, hemimorphite and smithsonite.

108 Gangue minerals include automorphous white carbonates, such as calcite and dolomite (Fig. 2D), emplaced during the early sulphide stage (Choulet et al. 2014). Willemite is finely associated to galena

110 remnant and cerussite, forming a well-defined black ore. Black ore generally occurs as disseminated 111 patches enclosed in very fine-grained clay-rich material (Fig. 2E), showing a variety of colours. Hence, 112 different types of clayey material have been distinguished and they are detailed in the following 113 section.

\section{3) The different types of clay deposits at Bou Arhous} the karstic cavities and were considered of detrital origin as evidenced by the layering structures. These 
clays are barren, but they locally contain some fragments of the non-sulphide mineralisation. In

121 contrast, white and granular clays are frequently associated to willemite and Leblanc (1968) suggested

122 that these clays might correspond to newly formed clay minerals with up to $23 \%$ of $\mathrm{Zn}$ (Gaudefroy

123 1953).

124 Based on a recent detailed field study, a new examination of the clay materials has been

125 carried out and we now distinguish three types of clayey material, which may coexist in a same area

126 (Fig. 3A).

127 1) Red clayey material fills a network of connected cavities, sinkholes and tunnels, related to the karst 128 of Bou Arhous (Fig. 3B). A sub-horizontal bedding (Fig. 3C) with evidence of grain size sorting is 129 frequently observed, as well as various-sized clastic fragments of ore and host limestone. The aspect of 130 the red clayey material may be locally smooth, but is often silty or sandy due to millimetre-sized quartz 131 grains. This red clayey material corresponds to the reddish and smooth clays described by Leblanc 132 (1968).

133 2) White clayey material occurs as a fine-grained matrix embedding disseminated patches of willemite 134 associated with carbonates and galena. It forms either a thin and partial rim between the black ore and 135 the red clays (Fig. 3D), or a widespread impregnation in the mineralisation (Fig. 3E). The white colour 136 is not systematic and tends be locally yellowish, indicating a progressive transition to ochre clays. This type partly encompasses the white granular type observed by Leblanc (1968).

138 3) A third type, namely ochre clays has been found as cavity-infilling material (Fig. 3F) or as a mixture 139 of white and red clayey materials (Fig. 3A). Ochre clays share similar features with white clays, such 140 as their association with black ore but this latter one is less preserved than in the case of white clays.

141 Ochre clays may also occur as isolated material without any spatial connection with white and red 142 clays.

144 4) Sampling and methodology

4.1) Bulk chemical composition 

analysing the chemical composition. The chemical composition measurements using acid digestion

152 procedure have been carried out in Managem Group lab, at Marrakech, Morocco. For major elements, $1530.5 \mathrm{~g}$ of a crushed sample $(<200 \mu \mathrm{m})$ has been dried and dissolved by fusion at $500^{\circ} \mathrm{C}$ during 45 154 minutes with $2.5 \mathrm{~g}$ of sodium peroxide in a zirconium crucible. The residue was then dissolved in $\mathrm{HCl}$ and the solution has been analysed by ICP-AES ULTIMA 2C. For minor elements, a $0.25 \mathrm{~g}$ split has

156 been heated $\left(220{ }^{\circ} \mathrm{C}\right.$ during 45 minutes) in $\mathrm{HCl}(50 \%)-\mathrm{HNO}_{3}(50 \%)$ to fuming and the solution was analysed by ICP-MS Thermo X'Serie 2.

\section{2) Clay fraction study}

In addition, for twenty-two samples, the clay fraction $(<2 \mu \mathrm{m})$ has been separated by decantation using the following procedure. A rock sample has been crushed using a Retsch PM200 ball mill and manually ground in agate mortar. The rock powder has been dissolved in distilled water and 164 dispersed with a magnetic stirrer. Progressive addition of $\mathrm{HCl}(0.2 \mathrm{M})$ monitored by continuous $\mathrm{pH}$ measurements was used to remove carbonate at room temperature. Then, the solution has been washed several times, dispersed and placed in a jar for decantation. After about 4 hours, the first five centimetres of the solution containing the clay suspension $(<2 \mu \mathrm{m})$ have been withdrawn using a syringe. After removing the supernatant by centrifugation, the residue has been dried and used for further X-ray diffraction (XRD) and cation-exchange capacity measurements. XRD patterns of the whole rock samples and clay fractions have been obtained using a D8

171 Advance Brucker diffractometer equipped with a LinxEye detector, hosted at Utinam lab, Besancon, 172 France. Parallel beam geometry and $\mathrm{CuK} \alpha$ radiation at $1.54184 \AA$ has been used. For whole rock sample, the powder was placed in the specimen holder. Acquisition conditions (divergent slit) included 174 a step-scan of $0.5^{\circ}$ in the $2-52^{\circ}$ interval, with a step time of $0.05 \mathrm{~s}$. For the clay fraction, the powder has been diluted in distilled water and a drop of the solution has been deposited on a glass lamella for

176 dewatering under air-dried conditions. The orientated-aggregate mount (along $\mathrm{c}$ axis) was then placed 177 in holder and a step-scan of $0.02^{\circ}$ in the $2-30^{\circ}$ interval, with a step time of $0.5 \mathrm{~s}$ has been used for 178 XRD measurements. A duplicate of the orientated-aggregate mount has been treated for ethylene glycol (EG) saturation, by placing the lamella in a pressurised desiccator overnight. For several 

measurements. EVA software package has been used for data processing and phase identification. The

182 position of 060 reflexion has been determined on clay fraction powders at Institut des Sciences de la 183 Terre d'Orléans, Orléans, France, using an ARL X’TRA diffractometer equipped with Cu anode and a 184 Si solid detector operating at $40 \mathrm{kV}$ and $40 \mathrm{~mA}$. Experimental measurements were carried out at room temperature, with $10 \mathrm{~s}$ counting time per $0.02^{\circ}$ step.

Cation-exchange capacity (CEC) measurements have been carried out at the Institut des Sciences de la Terre d'Orléans, Orléans, France following the procedures described in Meier and Kahr (1999) and Ammann et al. (2005). A solution of 0.01M Cu(II)-trien sulphate has been prepared from $1.596 \mathrm{~g}$ of copper sulphate and $1.508 \mathrm{~g}$ of triethylenetetramine. 100+/- $25 \mathrm{mg}$ of clay sample were 190 added to $25 \mathrm{~mL}$ of distilled water and to $8 \mathrm{~mL}$ of $\mathrm{Cu}$ (II)-trien sulphate. The solution has been dispersed 191 using tube roller overnight and was further centrifuged (10 minutes at $6000 \mathrm{rpm}$ ) to removed $3 \mathrm{~mL}$ of 192 the supernatant. Measurement of $\left[\mathrm{Cu}^{2+}\right]$ was performed using Atomic Absorption Spectroscopy (AAS) with 2-8100 Polarized Zeeman Hitachi instrumentation and colorimetric techniques. The CEC was then

194 calculated with reference to the dry clay weight, to the water content and to the amount of captured $\mathrm{Cu}^{2+}$ ions deduced from AAS measurements. A similar procedure is used for calculating the $\mathrm{Zn}$ content 196 in the CEC. Standardisation curves of absorbance for $\left[\mathrm{Cu}^{2+}\right]$ and $\left[\mathrm{Zn}^{2+}\right]$ gave coefficients of determination of 0.999 and 0.987 , respectively.

\section{3) Textural and mineralogical observations}

Textural and mineralogical observations have been carried out using optical microscopy (OM) and FEI Quanta 450 Scanning Electron Microscope (SEM) hosted at Femto-ST lab, Besançon, France. The images have been acquired in low vacuum mode (0.7-0.8 mbar) on polished thin sections, with 204 acceleration voltage at $15 \mathrm{kV}$. An Energy-Dispersive X-Ray Spectrometer (EDS) was coupled to the SEM system providing qualitative determination of the mineral composition using Edax Genesis software package. 
210 We have performed quantitative analyses using Cameca SX100 electron microprobe (EPMA),

211 equipped with five Wave-Dispersive X-Ray Spectrometers (WDS) and hosted at Géosciences

212 Montpellier, Montpellier, France. On carbon-coated polished thin-section, we have operated at $20 \mathrm{kV}$

213 with a beam current at $10 \mathrm{nA}$. The spot resolution was few micrometres. Quantification of the Na

214 content was not possible due to the interference of the $\mathrm{Zn} \mathrm{L} \beta 1$ emission line that fall close to the Na Ka

215 emission line.

216

217 4) Results

218

4.1) Whole rock geochemical and mineralogical composition

4.1.1) Host rocks

The Triassic shales are composed of a mixture of quartz, clay minerals, hematite, goethite, and carbonates including both calcite and dolomite (Table 1). Gypsum is also present in some samples. The major elements content strongly varies due to a variable proportion of carbonates and iron oxihydroxides. Variable enrichment in $\mathrm{Zn}, \mathrm{Pb}, \mathrm{Cu}$ and $\mathrm{As}$ can be noticed suggesting the local occurrence of sphalerite, galena, and/or other minor metal-bearing minerals.

Jurassic rocks including marl and limestone contain clay minerals, calcite, dolomite and quartz (Table 1). Goethite is common. The $\mathrm{SiO}_{2}$ and $\mathrm{CaO}$ contents are variable and probably mirror the variable abundance in quartz and carbonate in the samples. Minor elements $(\mathrm{Zn}, \mathrm{Pb}, \mathrm{Cu}$ and $\mathrm{As}$ ) content remains low except for one sample that contains galena, sphalerite and their respective alteration products.

\subsection{2) Clayey material}

234 The mineralogy of the red clayey material is characterized by a mixture of quartz, clay minerals, calcite with goethite and rare dolomite (Table 1). Despite important variations of $\mathrm{CaO}$ and

$236 \mathrm{SiO}_{2}$ related to carbonate enrichment of some samples (e.g. BA101), the major elements content remains constant. The red clay samples do not display any significant variations of the minor elements 
ppm for $\mathrm{Zn}$ ); this could be related to the occurrence of willemite and cerussite impurities in these samples.

The white clayey material is composed of a mixture of willemite, galena, quartz, clay minerals and carbonate (dolomite, calcite, and cerussite). Dolomite is almost always observed in white clays, marking a noteworthy difference with red clayey material. The $\mathrm{MgO}$ content can therefore reach up to $10 \%$ wt (Table 1). The occurrence of $\mathrm{Zn}$ and $\mathrm{Pb}$ ore in white clays is responsible for high $\mathrm{Zn}$ and $\mathrm{Pb}$ grade (up to $320000 \mathrm{ppm}$ for $\mathrm{Zn}$ and $37100 \mathrm{ppm}$ for $\mathrm{Pb}$ ).

In ochre clayey material, clay minerals, quartz, calcite and dolomite are always present, with a common occurrence of cerussite. Chemical compositions of the ochre and white clayey materials are relatively close; indeed they have similar $\mathrm{MgO}$ and $\mathrm{CaO}$ contents (Table 1). Despite the absence of $\mathrm{Zn}$ bearing phases (sulphide or carbonate) detected from whole-rock XRD analysis, the $\mathrm{Zn}$ content varies between $6275 \mathrm{ppm}$ and $237000 \mathrm{ppm}$.

The extreme variations of the $\mathrm{Zn}$ content in the three types of clayey material cannot be correlated straightforwardly to the mineralogical composition deduced from whole rock XRD measurement, it may be partly due to the presence of willemite impurities, but, for several samples (ochre clays), Zn-bearing clays must be involved to explain tremendous $\mathrm{Zn}$ contents, requiring a specific study of the clay fraction.

4.2) Mineralogical characterisation of the clay fraction

\subsection{1) Red clays}

XRD patterns obtained on the clay fraction of the red clays show a non-expandable phase around $7.1 \AA$ (Fig. 4A), which mainly corresponds to the 001 reflexion of kaolinite as this Bragg peak disappears after heating to $550{ }^{\circ} \mathrm{C}$. Chlorite is significantly present in the mixture as evidenced by the

265 (3.58 ̊). The non-expendable peak at $10 \AA$ A may suggest the presence of illite, whereas the $14.6 \AA$ peak that expands to $16.8 \AA$ for EG-treated preparations corresponds to swelling smectite. The broad shape 267 in the domain between smectite and illite 001 reflections suggests the presence of interstratified illite/smectite. By focusing on the position of the 060 reflection (Fig. 4B), a main broad peak at 1.49- 
$1.50 \AA$ is consistent with the predominance of dioctahedral species like kaolinite and illite, whilst the secondary peak at 1.541-1.543 $\AA$ corresponds to a trioctahedral type like chlorite. Quartz and goethite

271 are also present.

4.2.2) White clays

XRD patterns of white clays display two identified Bragg peaks at $7.25 \AA$ and $3.61 \AA$ that expand to $7.39 \AA$ and $3.53 \AA$, respectively, for samples treated with EG (Fig. 5A). This indicates the presence of randomly interstratified smectite and of another clay mineral, characterized at $7 \AA$ such as kaolinite or serpentine. This mixed-layered (ML) clay mineral, dominated by the $7 \AA$ phase, coexists with illite and occasional chlorite. Smectite was detected in samples BA130F and BA134F. Associated phases such as cerussite, willemite, goethite-and goethite commonly occur. Whilst the broad peak around $1.50 \AA$, typical of dioctahedral clays corresponds to the position of 060 reflexion of illite, the

281 thin well-defined peak at $1.54 \AA$ suggests a significant proportion of trioctahedral type clay minerals (Fig. 5B). Although this may be confused with the 1.541 A peak due to the 211 reflection of quartz, the 060 reflexion patterns are similar between samples which may (e.g. sample BA130F) or may not (e.g. sample BA124F) contain quartz (Fig. 5A). For sample BA124, the offset of the broad peak to $1.51 \AA$ is probably an artefact due to a parasite reflexion of zinc silicate (e.g. $11 \overline{6}$ for willemite or 530 for hemimorphite).

\subsection{3) Ochre clays}

XRD patterns of the ochre clays do not strongly differ to those of the white clays, with the presence of randomly interstratified smectite and $7 \AA$ mineral (Fig. 6A). But the shift of this Bragg peak to lower angular value after EG treatment (up to $7.72 \AA$ and $3.45 \AA$ ) suggests a higher smectite proportion in the ML. In addition, illite and smectite are also displayed, as well as cerussite and goethite. The predominance of the trioctahedral type over the dioctahedral type is obviously shown on the 060 reflexion pattern (Fig. 6B), with a well-defined thin peak around $1.542 \AA$ and a broad and 

possible trend between the type of clays and the amount of $\mathrm{Zn}$ content, it does not provide any

301 information on the localization of $\mathrm{Zn}$ within the phyllosilicate structure (i.e. in the interlayer space as an exchangeable cations or included in the phyllosilicate sheets). The CEC measurements represent an easy and convenient method allowing one to determine the proportion of exchangeable zinc in the three kinds of clay samples (Table 2). The CEC value of the red clays is between 30 and 38 meq/100g, consistent with a mixture of illite, kaolinite and smectite. For 3 out of 4 samples, the amount of exchangeable $\mathrm{Zn}$ represents less than $1 \%$ of the CEC and is therefore not significant. In contrast, for sample BA121, which may be considered as an exception, more than $40 \%$ of the CEC contains exchangeable $\mathrm{Zn}$; this may partly explain the high $\mathrm{Zn}$ content (30000 ppm) of this sample, but this assumption is not valid for other mineralized samples such as BA127 (Table 1). For the white clays, the CEC values are bracketed between 9 and $27 \mathrm{meq} / 100 \mathrm{~g}$; it may be related to the high content of ML

311 dominated by a non-swelling $7 \AA$ mineral, with a typical CEC value of 5 to $15 \mathrm{meq} / 100 \mathrm{~g}$ (Ma and

312 Eggleton 1999). In the ochre clays, the CEC values may reach $41 \mathrm{meq} / 100 \mathrm{~g}$, as the smectite proportion 313 in the ML is probably higher than in the white clays (Fig. 6A). The amount of exchangeable zinc in the 314 CEC is very low for both white and ochre clays, suggesting that zinc is mainly included within the 315 octahedral sites of the clay mineral structure.

\section{4) Textural observations (OM and SEM)}

SEM observations of the red clays confirm the presence of a mixture of clay minerals, with dense aggregates of clay platelets (Fig. 4C). EDS analyses show that clay minerals are composed of Si,

$321 \mathrm{Al}$, and $\mathrm{K}$, in accordance with the occurrence of illite/kaolinite mixture as identified on XRD patterns

(Fig. 4A). Isolated laths or sub-euhedral lamella of chlorite are associated to K-rich clays and quartz sub-rounded clasts too (Fig. 4C). The bulk clayey matrix displays lighter and porous aggregates of lamella-shaped minerals (Fig. 4D); EDS analyses of these patches show Zn enrichment and a low K content relative to the mixture of kaolinite and illite. Descloizite, a zinc vanadate that precipitates under high oxidizing weathering conditions has been locally found (Fig. $\mathbf{4 E}$ ) and may explain, together with the zinc clays, the anomalous high $\mathrm{Zn}$ content of some red clayey material samples (e.g. BA121 and 
BA127; Table 1). It is worth to notice that no particular phase corresponding to zinc clays was detected by XRD analyses suggesting a low abundance of these zinc-bearing minerals. Optical microscope observations of the white clays show that clay minerals occur in cavity

331 within the ore formed by roundish aggregates of willemite and disseminated galena coated by cerussite

332 (Fig. 5C). SEM imaging of the clayey material in these cavities reveals a roughly honeycomb texture of the newly formed clay minerals (Fig. 5D). Locally, the micrometre-sized clay sheets are densely 334 aggregated and form patches disseminated in the cavity. EDS analyses reveal that these clays are rich in $\mathrm{Zn}$ and poor in $\mathrm{K}$, but sometimes K-rich fragments are found, suggesting an intricate association of both clay types. In most cases, the electronic contrasts between dark K-rich clays and light Zn-rich clays are so clear that it is easy to separate to the related domains, which present a very different textural arrangement (Fig. 5E). In the K-rich zone, the illite lamellae coexist with sub-euhedral clasts of quartz. Thin to large bands of Zn-rich clays exposing a honeycomb texture pervade in the cavity and connect to the willemite crystals. filled by clay minerals within a primary association of willemite, dolomite and cerussite (Fig. 6C). A honeycomb texture of Zn-rich clays analysed by EDS is frequently observed (Fig. 6D). In the weakly

344 dense aggregates, the micrometre-sized clay crystals can be individualised, exposing a typical sheeted aspect. Relics of illite lamellae and clasts made of quartz are found isolated in the Zn-rich clay matrix (Fig. 6E).

The clay minerals and especially the zinc-bearing type are closely associated to willemite; euhedral willemite crystals present evidence of partial dissolution that preferably affects edges or sites of crystalline defect (Fig. 7A). Zinc clays may precipitate in this newly formed porosity (Fig. 7B), but are mainly found as flakes or platelets either within the K-rich clayey material composed by illite, kaolinite and chlorite (Fig. 7C) or along cleavage cracks to form mineralized ribbons (Fig. 7D) that fossilized the paths of reactive waters. The honeycomb texture of newly formed zinc clays is frequent in the core of the domain, whereas the clay sheets appear squeezed at the interface with willemite

354 (Figs. 5E and 7E). Together with the euhedral shape of the willemite crystal and the evidence of successive rims of willemite, this supports the crystallization of a second generation of willemite (willemite II in Fig. 7F) after the formation of the Zn-rich clays. 
WDS quantitative measurements have been carried out on clay aggregates from white and ochre types (samples BA02, BA05 and BA05) and the results are reported in Table 3. Only data with a total over $80 \% \mathrm{wt}$, consistent with the range of expected zinc clays minerals (fraipontite, sauconite) have been retained for discussion. The $\mathrm{ZnO}$ content, between $1.86 \%$ and $49.39 \%$ appears negatively correlated to the $\mathrm{K}_{2} \mathrm{O}$ content varying from $10.01 \%$ to $0.05 \%$. Similarly, the $\mathrm{SiO}_{2}$ and $\mathrm{Al}_{2} \mathrm{O}_{3}$ contents decrease with $\mathrm{K}_{2} \mathrm{O} . \mathrm{Ca}, \mathrm{Fe}, \mathrm{Mg}$ and $\mathrm{Pb}$ cations are present in minor amount and we observe show slight variations without any relationships with other major elements. Several groups depending on their $\mathrm{ZnO}$ and $\mathrm{K}_{2} \mathrm{O}$ content and their total oxide content have been distinguished (Table 3). For K-rich clayey material, structural formulae were calculated for 22 negative charges (Table 3). For analyses 10, 57 and 58, the number of octahedral cations is around 2 and the number of interlayered cations reaches 0.8 , consistent with the occurrence of illite. Analyses 19, 20, 29 and 38 show a significant $\mathrm{K}_{2} \mathrm{O}$ content (around $2 \%$ ) and $\mathrm{Zn}$ enrichment up to $30 \%$; they present a total of analysed oxides around $84 \%$ consistent with pure $\mathrm{Zn}$ smectite, i.e. sauconite (Table 3). For seven individuals analyses that present a total of analysed oxides around $93 \%$ and a $\mathrm{K}_{2} \mathrm{O}$ content between 0.2

$374 \%$ and $0.6 \%$, structural formulae were calculated for 22 negative charges assuming a T-O clay mineral structure. The number of cations in octahedral sites is around 5.5 attesting that the analysed particles are trioctahedral $\mathrm{Zn}$-rich $\mathrm{T}-\mathrm{O}$ minerals such as fraipontite. The value of $\mathrm{M}^{+}\left(\mathrm{M}^{+}=\mathrm{K}+2 \mathrm{Ca}\right)$ is significantly high, and may mirror surface adsorption of alkaline cations. The 17 remaining analyses display a total oxide between $84 \%$ and $93 \%$ and/or a variable content in $\mathrm{K}_{2} \mathrm{O}$; they probably correspond to a mixture of the above-mentioned end-member clay minerals. The structural formulae 380 calculations were based on 22 negative charges. One can notice the number of cations in the octahedral sites (3.4-3.5) largely exceed the ideal value of 3 (Table 3).

\section{5) Discussion}



Zn-bearing clays in the three types of clayey material at Bou Arhous mine, especially in the white and ochre types. By comparing the results given by the two methods, we can deduce that the zinc-rich sheeted aggregates disseminated in the samples correspond to a $7 \AA$ mineral locally interstratified with smectite sheets. In the literature, several types of zinc clays have been described. Sauconite, a trioctahedral smectite close to saponite is the most described clay type and was reported in several deposits in Northern America (Ross 1946), Peru (Boni et al. 2009a), Southern Africa (Kärner 2006; Terraciano 2008; Boni et al. 2011) and Iran (Daliran et al. 2009). Fraipontite (also known as zinalcite), a zincian berthierine ( $7 \AA$ mineral) has been found in supergene zinc deposits in Belgium (Fransolet and Bourguignon 1975), Iberia (Calvo et al. 2007; Will et al. 2014), Italy (Merlino and Orlandi 2001) and Kazakhstan (Chukhrov 1968). Other rare zinc clays are Zn-rich beidellite (Mondillo et al. 2014), baileychlore, a zinc chlorite (Rule and Radke 1988) and hendricksite, a zinc mica (Frondel and Ito 1966; Robert and Gaspérin 1985), the latter two occurring in hypogene environments. Besides, moresnetite (Ross 1946) and vanuxemite (Frondel 1972) have been described 401 as a mixture of zinciferous clays and hemimorphite. No zinc-bearing mixed-layered (ML) minerals have been described, except for illite-zincian smectite ML in Peru (Mondillo et al. 2014). In this study, the WDS compositions of the clay crystals show a negative correlation between

$404 \mathrm{~K}$ (as well as $\mathrm{Al}$ and $\mathrm{Si}$ ) and $\mathrm{Zn}$, suggesting phase mixing at site of analysis (Table 3). This is in 405 agreement with the microscopic observation that supports an intricate association between the K-rich and the $\mathrm{Zn}$-rich clays. In the $\mathrm{M}^{+}-4 \mathrm{Si}-3 \mathrm{R}^{2+}$ ternary plot, classically used for distinguishing the 407 dioctahedral and the trioctahedral types (Meunier 2005), our data are scattered along a mixing line that joins the mica pole and the most frequent Zn-clays, namely sauconite and fraipontite (Fig. 8). The data

409 corresponding to the purest Zn-clays do not fall into fields of natural sauconite or fraipontite collected

410 in Peru (Boni et al. 2009a; 2009b), in Namibia (Kärner et al. 2006), in the USA (Ross 1946), in UK 411 (Young et al. 1992) and in Belgium (Fransolet and Bourguignon 1975); data rather fall into an 412 intermediate domain between the theoretical compositions of sauconite and fraipontite. Together with 413 the difficulty of calculating pure sauconite or fraipontite structural formula from our analyses (Table 414 3), this indicates that our zinc clayey material is dominantly a mixture of fraipontite and sauconite, in 415 agreement with the occurrence of interstratified smectite and $7 \AA$ mineral. 
417 been carried out to determine the relative proportions of fraipontite and sauconite in the ML mineral.

418 Assuming 1) a mixture of a two-water-layer tri-smectite and a $7 \AA$ mineral, 2) the $00 l$ reflexions given

419 by Faust (1951) and Fransolet and Bourguignon (1975), and 3) a Reichweite value of 0, we have 420 produced the XRD patterns presented in Figure 9. In this calculation, we have neglected the minor 421 effects of $\mathrm{Zn}^{2+}$ on the geometry of ML structure and therefore on the theoretical positions of 001 422 reflexions. The best simulation to describe the measured XRD pattern is obtained for a mixture 423 containing $80 \%$ of fraipontite and $20 \%$ of sauconite, namely R0 fraipontite (0.8)/sauconite (Fig. 9). To 424 validate this composition, we have recalculated the structural formula assuming a mixing of sauconite and fraipontite at a ratio of 1:4. Based on 390, the sum of cations in the octahedral sheets is between 42614.2 and 15 for low $\mathrm{K}_{2} \mathrm{O}$ individual data; this value, slightly lower than the ideal value of 15 for the trioctahedral type corroborates the hypothesis of R0 fraipontite( 0.8$) /$ sauconite mixed-layered mineral as the zinc-bearing clay mineral. Although such composition of interstratified mineral has never been reported in the literature, the occurrence of the sauconite-fraipontite association has been described in several natural examples of supergene non-sulphide zinc deposits (Foord et al. 1983; Young et al. 1992; Maltsev and Korshunov 1988), or even found in experimental works (Esquivin 1957; 1960).

\section{2) Genetic processes accounting for Zn-clays formation}

Results obtained on whole-rock samples show the difficulty of identifying significant differences between the three types of clayey material to understand their genetic link with the ore and the host rock. Despite these difficulties, the following implications may be deduced from the above-mentioned analysis:

- Dolomite is present in the Jurassic limestone and in the gangue of $\mathrm{Zn}-\mathrm{Pb}$ ore. Its occurrence

440 in the ochre and white clayey materials and its relative absence in the red one may indicate different genetic processes accounting for their respective origin

- Microscope observations have shown that Zn-clays are very frequently associated to detrital

443 illite, which is dominant in the red clayey material. Zinc enrichment of clay minerals in the white and 444 ochre clayey materials is consistent with the neogenesis of mixed layered fraipontite $(0.8) /$ sauconite minerals, requiring sources for zinc, silica and aluminium. 

remain unclear (Choulet et al. 2014). It may have been formed under supergene conditions as 448 exemplified by the deposits in Nevada (Takahashi 1960), or in Zambia (Terraciano 2008). Alternatively, a hydrothermal or hypogene origin for willemite (Brugger et al. 2003; Hitzmann et al. 2003, Boni et al. 2011) could be envisaged, but no field and mineralogical observations are currently supporting this hypothesis.

The origin of willemite in such supergene environment is not clearly understood as this mineral is mostly described in hypogene or hydrothermal deposits (Hitzman et al. 2003; Coppola et al. 2008). Its occurrence at Bou Arhous may suggest either a low-temperature hydrothermal stage or exceptional physico-chemical conditions characterised by a combination of high silica activity, low $\mathrm{P}\left(\mathrm{CO}_{2}\right)_{\mathrm{g}}$, alkaline conditions and oxidizing environment (Choulet et al. 2014). At $25^{\circ} \mathrm{C}$, willemite may be partly dissolved by meteoric waters rich in $\mathrm{Ca}$ and poor in $\mathrm{Si}$ (Brugger et al. 2003); such conditions are reached in karst environment because of water-host rock interaction. This can explain the evidence for supergene dissolution of willemite, releasing $\mathrm{Zn}$ and $\mathrm{Si}$ in the solution (Figs. 7A and 7B). This dissolution is probably congruent as no quartz or silica gel, incorporating the silicon in excess, remains or precipitates in the secondary porosity. The addition of $\mathrm{Zn}$ and $\mathrm{Si}$ ions in the solution changes equilibrium and the solubility of the Zn-bearing phases strongly depends on the $\mathrm{pH}$ conditions

(Takahashi 1960; Brugger et al. 2003). As no smithsonite or hydrozincite precipitation has been observed in our samples despite high $\mathrm{P}\left(\mathrm{CO}_{2}\right)_{\mathrm{g}}$ due to karst buffering, slightly acid (ca. 5) conditions must be envisaged to transport the $\mathrm{Zn}^{2+}$ ions as chlorozinc(II) complexes (Ruaya and Seward 1986) and to enable a further precipitation of zinc clays. The absence of widespread hemimorphite is difficult to understand, as this phase is supposed to precipitate under acid $\mathrm{pH}$ conditions and relatively high silica activity (Takahashi 1960; McPhail et al. 2003); however, this may be explained by the limited field of hemimorphite stability and its sensibility to strong $\mathrm{P}\left(\mathrm{CO}_{2}\right)_{\mathrm{g}}$ variations (Reichert and Borg 2008).

The availability of $\mathrm{Al}$ is also critical for the neogenesis of the $\mathrm{Zn}$ clays, and requires a local

473 K-rich clays, mainly illite as evidenced by the XRD patterns of the white and ochre clayey materials.

474 At the scale of the cavity, the pervasion of the $\mathrm{Zn}$-rich clays in the material dominated by the K-rich clays shall suggest a pseudomorphosis of primary illite and smectite and their replacement by the 
mixed-layered clay minerals (Figs. 5D or $6 \mathbf{E}$ ). The very close association of illite and $\mathrm{Zn}$ clays suggests that partial dissolution of external illite layers, due to hydrolysis and the break up of Al-O and

$478 \mathrm{Si}-\mathrm{O}$ bonds, contributes to releasing $\mathrm{Al}$ and $\mathrm{Si}$, further incorporated in the newly formed $\mathrm{ML}$ clay minerals. The Zn clays may also pseudomorph after dissolved willemite (Fig. 7B), but this requires a close source for $\mathrm{Al}$.

In karstic environments, the physico-chemical conditions of meteoric waters continuously change due to carbonate buffering. A rapid increase of $\mathrm{pH}$ causes tremendous variations of the solubility of zinc silicates like willemite that can further precipitate even at surface temperature and under neutral conditions (Brugger et al. 2003). This precipitation of secondary willemite (Willemite II) forming euhedral rim around primary willemite (willemite I) leads to squeezing of newly formed zinc clays (Fig. 7E and 7F). As a consequence, the honeycomb texture is locally erased, and jamming contributes to emphasize the very fine mixing between illite and ML clay minerals (Fig. 7E). Secondary willemite also occurs as idiomorphic crystals in the open space of the clayey cavities (Fig.

\section{3) Conditions for Zn mineralisation of clays and relation to the ore evolution}

The mechanisms of $\mathrm{Zn}$-rich clays formation have been rarely reported in the literature. In $\mathrm{Zn}$

494 ore deposits of Peru, Boni et al. (2009a) have identified sauconite and altered feldspars and they proposed that sauconite in silicoclastic host rocks may result from interaction between feldspar weathering and $\mathrm{Zn}$-rich solution derived from supergene dissolution of zinc sulphide. At Abenab West ore deposit (Namibia), hosted in limestone, a progressive enrichment in $\mathrm{Zn}$ and $\mathrm{Mg}$ of barren clays is suggested, but details of the nature of zinc clays and the processes related to their neogenesis are presently not available (Terraciano 2008).

Like Abenab West ore deposit, zinc ore at Bou Arhous is hosted in limestone that has developed a large karst network since its exhumation at surface (Leblanc 1968). The Bou Arhous karst presents some non-dissolved material concentrated in various-sized cavities. Field observations have shown that this red clayey material is composed by a fine succession of silt and clay horizons that

504 present sedimentation features. The red clay type may correspond to "residual" clays, which generally show mixing components between detrital sources and insoluble parts of the dissolved limestone 
506 (Chamley 1989). The residual red clays are composed of clay minerals like illite, chlorite, kaolinite

507 and smectite, iron oxi-hydroxide and quartz. This composition is somehow similar to that of the 508 classical peri-Mediterranean karst-related clayey infilling, known as terra rossa, that shows stratiform 509 accumulation of red clayey material in cavity formed after limestone dissolution (e.g. Blanc and 510 Chamley 1975; Moresi and Mongelli 1988; Iacoviello and Martini 2013).

511 The red clays are originally barren (Table 1), but may be fertilized by several complementary 512 processes that includes: typical of high oxidising supergene environment (Boni et al. 2007).

- Adsorption of the $\mathrm{Zn}^{2+}$ cations at the clay surface or fixing of the $\mathrm{Zn}^{2+}$ cations in the interlayer, as indicated by the amount of $\left[\mathrm{Zn}^{2+}\right]$ released after the CEC measurements (Table 2). This 518 process is well known in the literature as many studies have focused on the capacity of clays to trap heavy metals like Zn (e.g. Bradbury and Baeyens 1999; Dähn et al. 2011). - Precipitation of the Zn-rich clays in small-disseminated patches (Fig. 4D), up to large pervasion (Figs. 5D and 6E) in the red detrital clayey material. This process is able to progressively 522 form the white or the ochre clays found in the Bou Arhous deposit. As seen earlier, this process is 523 characterized by the neogenesis of authigenic clay minerals that nucleate on micas. It may be compared 524 to the epitaxial growth of $\mathrm{Zn}$ clays on smectites, which interacts with a solution enriched in $\mathrm{Zn}$ and $\mathrm{Si}$ 525 (Schlegel et al. 2001; Schlegel and Manceau 2006). These authors reported newly formed clays as a 526 mixture of Zn-saturated TO and TOT trioctahedral phyllosilicates, thereby presenting lot of similarities 527 with the R0 fraipontite(0.8)/sauconite mixed-layered mineral identified in this study. The presence of a 528 clay precursor for nucleation and $\mathrm{Al}$ supply is required for the neogenesis of $\mathrm{Zn}$-clays, which also 529 depends on the silica activity (Schlegel et al. 2001). At low Si concentration, $\mathrm{Zn}$ may be fixed in 530 polymer chains in structural continuity to the smectite. High Si concentration rather facilitates the 531 neogenesis of authigenic clays and especially the formation of $\mathrm{Zn}$-rich TO phyllosilicates, such as 532 fraipontite. Other experimental studies at supergene conditions have showed that the presence of Al 533 may play a role for the type of clay that precipitates (Tiller and Pickering 1974), with 2:1 layer 534 silicate in Al-free conditions and, in the presence of aluminium, formation of 1:1 layer silicate similar 535 to Zn berthierine, a synthetic product equivalent to fraipontite (Esquevin 1960). Such chemical 
controls could be hypothesised to spell out the different types of $\mathrm{Zn}$ clays met throughout the world.

537 The climate dependence classically evoked for the variability of clay types (Chamley 1989) may also

538 be taken into account, but its role is currently difficult to understand, given the scarcity of reliable data on Zn clay occurrences.

The formation of zinc clays at Bou Arhous is a continuous process during the late supergene evolution of the ore deposit. Initially, zinc was included in sulphide lenses hosted in the Lower Jurassic limestone (Leblanc 1968). The regional uplift and the folding episode related to the Atlas tectonics during the Tertiary have led to an exhumation of the sulphide ore and a verticalisation of the limestone strata (Choulet et al. 2014). As a consequence, the meteoric water has percolated in the fractures and has provoked the dissolution of the limestone and the oxidation of the sulphides. For some unclear reasons, zinc has first re-precipitated as willemite, forming a "black ore" due to its association with preserved galena and cerussite. Willemite has further interacted with karstic waters, probably poor in $\mathrm{Si}$ and slightly acid, leading to its partial dissolution and to releasing of $\mathrm{Zn}$ and $\mathrm{Si}$ in the solution (Fig. 10). In parallel, the development of a karst was characterised by the opening of various-sized dissolution cavities filled by detrital supplies and insoluble materials (Fig. 10). At surface conditions, this red clayey material has been pervaded by $\mathrm{Zn}$-Si-rich solutions resulting in the neogenesis of $\mathrm{Zn}$ clays (mixed-layered clay minerals) that nucleate on detrital micas. At site of zinc ore concentration, red clays were progressively transformed into white and ocher clays. The further crystallisation of late generations of willemite indicates that this process is continuous in time, highly dependant on the chemistry and dynamics of karstic solutions, and therefore difficult to timely constrain in the ore deposit evolution.

\section{6) Conclusion}

This study has revealed the nature of the zinc clays at Bou Arhous deposit and the

562 of barren clays, the crystallisation of $\mathrm{Zn}$ clays appears to be the major one. This neogenesis is related to

563 the interaction between $\mathrm{Zn}$-rich meteoric water and residual clays related to karst evolution. This model

564 has strong implication for the mineral industry, as $\mathrm{Zn}$-rich clayey material grading up to $30 \% \mathrm{Zn}$ is a non-negligible resource that may be easily identified. The target zones will be the karst cavities located 
around the original ore body (potentially dissolved); residual clays must fill these cavities, representing the necessary condition for the nucleation of the newly formed clay crystals. The soft nature of the clayey material could probably facilitate mining, at least in case of open-pit extraction, and especially contributes to costs reduction in the early operations. Conversely, by deciphering the mineralogical nature of the $\mathrm{Zn}$-rich clayey material, this study has showed the mixture of authigenic mixed-layered clays and detrital phyllosilicates. Except for rare samples, zinc cannot be recovered easily as it is located within the octahedral sites in each component of the interstratified mineral. Consequently, Zn can only be released by leaching techniques such as 574 solvent extraction, which is relatively efficient for a given clay species like sauconite (Boni et al. 2009b). But, in the presence of interstratified minerals finely disseminated within detrital barren clays, ore liberation may be more difficult and requires advances for 1) an efficient separation between barren and mineralised clays, and 2) a better selectivity of solvents used. Another consequence of this intricate mineralogical association is the excess of barren materials that need to be handled and processed, thereby representing a major limitation to the economic potential of zinc clays.

\section{Acknowledgments}

The authors are indebted to Managem Company for providing access to the Bou Arhous Mine and for having supported bulk rock analyses in their labs. We also thank Goka Katrawi for CEC measurements and Didier Convert-Gaubier for thin-section preparation. This study has benefited from a research grant given by the Région Centre for the 2011-2014 CALAMINES project and from a financial support of Région Franche-Comté with the 2014 "Franco-Suisse" call. Access to SEM facilities of the MIMENTO centre was made in the frame of cooperative projects in the Renatech network.

\section{Figure Captions}

592 Fig. 1 a: Simplified tectonic map of Morocco. b: Geological map of the Bou Arhous range. c: Cross593 Section across the Bou Arhous range, showing the structural and stratigraphic location of the ore 594 deposit (modified after Choulet et al. 2014) 
596 Fig. 2 a: Non-sulphide ore veins cropping out at the surface. b: Lower Jurassic host rock composed of

597 limestone and marl strata. c: Triassic variegated shale inside the mine. d: Preserved sulphide associated

598 to calcite and willemite in a "black ore" vein. e: Illustration of the different types of clayey material with relationships to "black ore"

601 Fig. 3 a: Association of red clays and white to ochre clays inside the mine. b and c: Details of the 602 interconnected karst cavities, filled by red clayey material showing shallow inclined bedding. d: White clays at the interface between the black ore and the red clays. e: Large occurrence of white clays around black ore. f: Cavity filled by ochre clays spotted by relics of black ore

606 Fig. 4 a: XRD patterns of representative samples of red clayey material (oriented clay fraction preparation). See text for details about Bragg peaks indexation. Black (red) curves were obtained in dry

608 (Ethylene glycol (EG)) conditions. Sm: smectite, K: kaolinite, Ill: illite, Chl: chlorite, Qz: quartz, Goe: goethite. b: XRD patterns (misoriented clay fraction preparation) emphasizing the position of 060 reflections for representative samples of red clayey material. c to e: BSE images of red clays

611 illustrating the detrital origin of this material that contains a mixture of chlorite, illite, smectite, quartz 612 clasts and secondary Zn-rich mineral patches

614 Fig. 5 a: XRD patterns of representative samples of white clayey material (oriented clay fraction preparation) Sm: smectite, Ill: illite, ML: mixed-layers, Will: willemite, Cc: cerusite, Qz: quartz. b:

616 XRD patterns (misoriented clay fraction preparation) emphasizing the position of 060 reflections for representative samples of white clayey material. c: Illustration of cavities filled with white clays inside 618 the black ore (transmitted light, crossed nichols). d: BSE image of the mixture of Zn-rich clays and Krich clays, with light grey patches composed by Zn-rich clays. e: BSE image of zinc clays aggregate in cavities filled by detrital clays and relationships between clays and willemite crystals

622 Fig. 6 a: XRD patterns of representative samples of ochre clayey material (oriented clay fraction preparation) Sm: smectite, Ill: illite, ML: mixed-layers, Will: willemite, Qz: quartz; b: XRD patterns

624 (misoriented clay fraction preparation) emphasizing the position of 060 reflections for representative samples of ochre clayey material. c to e: BSE images of the ochre clayey material. c: relationships 
626 between zinc clays and ore and gangue minerals (willemite, cerussite and dolomite). d and e: Detailed

627 view of the zinc clays, with disseminated relics of detrital micas and quartz

629 Fig. 7 Secondary (a and f) and back-scattered (b to e) electron images of willemite and zinc clays in 630 black ore and white to ochre clay samples. a: partially dissolved willemite crystal with clay particles on

631 its surface. b: Neogenesis of authigenic zinc clays that precipitate in the void created by the partial 632 dissolution of a willemite crystal. c: Newly formed zinc clays flakes precipitating on detrital micas 633 surfaces. d: Ribbon-like aggregates of zinc clays filling the space between detrital clays. Note the 634 precipitation of late euhedral willemite crystals (willemite II) in the porosity. e: Pervasive enrichment in zinc clays of a geode initially filled by detrital clays. Note the idiomorphic willemite crystals close to 636 squeezed zinc clays; this crushed texture suggests willemite growth after zinc clays formation. f: Polyphase crystallization of willemite, showing growth zoning and fracture infilling

Fig. $84 \mathrm{Si}-\mathrm{M}^{+}-3 \mathrm{R}^{2+}$ diagram, illustrating the mixture of di- and tri-octahedral end-members. Our data 640 are plotted as square symbols and are compared with data reported in the literature. Colour assignment 641 matches the different types as showed in Table 3. Red: mica, green: fraipontite, blue: sauconite and 642 black: mixture of these three end-members

644 Fig. 9 Calculated XRD patterns given by Newmod modelling. Black (red) curves were obtained in dry (Ethylene glycol (EG)) conditions. See text for data inputs and implications

Fig. 10 Schematic view illustrating the formation of zinc clays in a mineralised karstic environment.

648 The relationships between the black ore (supergene non-sulphide ore) and the residual clays are emphasized. The two BSE images show the detrital texture of red clays before zinc mineralisation (right) and the honeycomb texture of white to ochre clays after neogenesis of zinc clays (left)

652 Table 1 Sampling details of the host rocks and clayey material, with bulk mineralogy deduced from

653 XRD and geochemical content obtained by ICPMS analyses. Abbreviations: cc: calcite, ce: cerussite, 654 cl: clays, do: dolomite, ga: galena, goe: goethite, gy: gypsum, he: hematite, qtz: quartz 
Table 2 Values of the CEC and zinc content of the CEC for the three types of clay materials reported in this study. The clay content is deduced from XRD analyses and is illustrated in figs 4 to 6

Table 3 WDS results and calculated structural formulae for the different types of clay minerals and aggregates. See text for explanation about calculation and data sorting

661

\section{References}

663

664 Abkhoshk E, Jorjani E, Al-Harahsheh MS, et al (2014) Review of the hydrometallurgical processing of non-sulfide zinc ores. Hydrometal 149:153-167. doi: 10.1016/j.hydromet.2014.08.001

666 Ammann L, Bergaya F, Lagaly G (2005) Determination of the cation exchange capacity of clays with copper complexes revisited. Clay Minerals 40:441-453. doi: 10.1180/0009855054040182

Bayraktar I, Aslan A, Ersayin S (1998) Effects of primary slime and clay on selectivity of flotation of sub-volcanogenic complex polymetallic ores. Trans Instit Min Metal Sect B Applied Earth Sci 107:C71-C76

Blanc J, Chamley H (1975) Remplissages de réseaux karstiques à la grotte de Saint-Marcel d'Ardèche. Quaternary 12:71-82. doi: 10.3406/quate.1975.2084 (in French)

Boni M, Large D (2003) Nonsulfide Zinc Mineralization in Europe: An Overview. Econ Geol 98:715729. doi: $10.2113 /$ gsecongeo.98.4.715

Boni M, Terracciano R, Evans NJ, et al (2007) Genesis of Vanadium Ores in the Otavi Mountainland, Namibia. Econ Geol 102:441-469. doi: 10.2113/gsecongeo.102.3.441

Boni M, Balassone G, Arseneau V, Schmidt P (2009a) The Nonsulfide Zinc Deposit at Accha 10.2113/gsecongeo.104.2.267

Boni M, Schmidt PR, De Wet JR, et al (2009b) Mineralogical signature of nonsulfide zinc ores at Accha (Peru): A key for recovery. Int $J$ Mineral Processing 93:267-277. doi: 10.1016/j.minpro.2009.10.003

Boni M, Terracciano R, Balassone G, et al (2011) The carbonate-hosted willemite prospects of the Zambezi Metamorphic Belt (Zambia). Miner Deposita 46:707-729. doi: 10.1007/s00126-011-0338- 
Bradbury MH, Baeyens B (1999) Modelling the sorption of Zn and Ni on Ca-montmorillonite. Geoch Cosmoch Acta 63:325-336. doi: 10.1016/S0016-7037(98)00281-6

Brugger J, McPhail DC, Wallace M, Waters J (2003) Formation of Willemite in Hydrothermal Environments. Econ Geol 98:819-835. doi: 10.2113/gsecongeo.98.4.819

690 Calvo M, Viñals J, Triviño A (2007) Zálesiíte, felsobanyaite and fraipontite, in a conglomerate in Prullans, La Cerdanya, Catalonia (Spain). Mineral Up I:49-51

692 Chamley H (1989) Clay sedimentology. Springer-Verlag, Berlin Heidelberg

Choulet F, Charles N, Barbanson L, et al (2014) Non-sulfide zinc deposits of the Moroccan High Atlas: Multi-scale characterization and origin. Ore Geol Rev 56:115-140. doi:

696 Chukhrov FV (1968) Some Results of the Study of Clay Minerals in the U.S.S.R. Clays and Clay Minerals 16:3-14. doi: 10.1346/CCMN.1968.0160103

698 Churakov SV, Dähn R (2012) Zinc Adsorption on Clays Inferred from Atomistic Simulations and EXAFS Spectroscopy. Environ Sci Technol 46:5713-5719. doi: 10.1021/es204423k

700 Connelly (2011) High clay ores: a mineral processing nightmare part 2. Australian J Mining 4

701 Coppola V, Boni M, Gilg HA, et al (2008) The “calamine" nonsulfide $\mathrm{Zn}-\mathrm{Pb}$ deposits of Belgium: 702 Petrographical, mineralogical and geochemical characterization. Ore Geol Rev 33:187-210. doi: 10.1016/j.oregeorev.2006.03.005

704 Crundwell F, Moats M, Ramachandran V, et al (2011) Extractive Metallurgy of Nickel, Cobalt and Platinum Group Metals. Elsevier, Oxford

706 Dähn R, Baeyens B, Bradbury MH (2011) Investigation of the different binding edge sites for $\mathrm{Zn}$ on montmorillonite using P-EXAFS - The strong/weak site concept in the 2SPNE SC/CE sorption model. Geoch Cosmoch Acta 75:5154-5168. doi: 10.1016/j.gca.2011.06.025

Daliran F, Armstrong R, Borg G, et al (2009) Nonsulphide Zinc Deposits, Iran - The Hypogene

710 Emplacement and Supergene Modification History of the Angouran Zinc Deposit, NW-Iran.

711 Bundesanstalt für Geowissenschaften und Rohstoffe

712 De Wet JR, Singleton JD (2008) Development of a viable process for the recovery of zinc from oxide ores. J South Afr Instit Mining Metal 108:253 
714 Esquevin J (1957) Sur la composition minéralogique des moresnétites et l'existence probable d'une 715 nouvelle phyllite zincifère. Comptes Rendus de l'Académie des Sciences (Paris) A/3150:4022. (in 716 French)

717 Esquevin J (1960) Les Silicates de zinc, étude de produits de synthèse et des minéraux naturels. Institut 718 national de la recherche agronomique, Saint-Amand (in French)

719 Faust GT (1951) Thermal analysis and X-ray studies of sauconite and of some zinc minerals of the 720 same paragenetic association. Am Mineral 36:795-822

721 Foord EE, Taggart JE, Conklin NM (1983) Cuprian fraipontite and sauconite from the Defiance-Silver Bill mines, Gleeson, Arizona. Mineral Record 14:131-132

Fransolet A-M, Bourguignon P (1975) Données nouvelles sur la fraipontite de Moresnet (Belgique). Bull Soc Fr Mineral 98:235-244

Frizon de Lamotte D, Leturmy P, Missenard Y, et al (2009) Mesozoic and Cenozoic vertical movements in the Atlas system (Algeria, Morocco, Tunisia): An overview. Tectonophysics 475:928. doi: $10.1016 /$ j.tecto.2008.10.024

Frondel C (1972) The minerals of Franklin and Sterling Hill, a checklist. Wiley-Interscience, New

730 Frondel C, Ito J (1966) Hendricksite, a new species of mica. Am Mineral 51:1107-1123

731 Fuerstenau MC, Jameson GJ, Yoon R-H (2007) Froth Flotation: A Century of Innovation. SME, $732 \quad$ Englewood

733 Gaudefroy C (1959) Kaolinite et montmorillonite zincifères (sauconite?) d'Iboughalène. Not Mem du $734 \quad$ Serv Geol Maroc 144:152-153

Gnoinski J (2007) Skorpion Zinc: optimization and innovation. J South Afr Instit Mining Metal 107:657-662

Hitzman MW, Reynolds NA, Sangster DF, et al (2003) Classification, Genesis, and Exploration Guides for Nonsulfide Zinc Deposits. Econ Geol 98:685-714. doi: 10.2113/gsecongeo.98.4.685 Senese karst massif (Italy). Geol Quarterly 57:527-536

741 Kärner K (2006) The metallogenesis of the Skorpion non-sulphide zinc deposit, Namibia. Dissertation, Univerität Martin Luther 
Leblanc M (1968) Etude géologique et métallogénique du jbel Bou-Arhous et de son prolongement oriental (Haut Atlas marocian oriental). Not Mem Serv geol Maroc 206:117-206 (in French)

745 Lim J (2011) Controlling clay behaviour in suspension: developing a new paradigm for the minerals industry. Dissertation, University of Melbourne

Ma C, Eggleton RA (1999) Cation Exchange Capacity of Kaolinite. Clays and Clay Minerals 47:174180. doi: 10.1346/CCMN.1999.0470207

Maltsev V, Korshunov V (1998) Geochemistry of fluorite and related features of the Kugitangtou Ridge Caves, Turkmenistan. J Caves Karst Stud 60:151-155

Mattauer M, Tapponnier P, Proust F (1977) Sur les mecanismes de formation des chaines intracontinentales; l'exemple des chaines atlasiques du Maroc. Bull Soc Geol fr S7-XIX:521-526. doi: 10.2113/gssgfbull.S7-XIX.3.521 (in French)

McPhail DC, Summerhayes E, Welch S, Brugger J (2003) The geochemistry and mobility of zinc in the regolith. Cooperative Research Centre for Landscape Environments and Mineral Exploration http://crcleme.org.au/Pubs/Advancesinregolith/AdvancesinRegolith.html.

Meier LP, Kahr G (1999) Determination of the Cation Exchange Capacity (CEC) of Clay Minerals Using the Complexes of Copper(II) Ion with Triethylenetetramine and Tetraethylenepentamine. Clays and Clay Minerals 47:386-388. doi: 10.1346/CCMN.1999.0470315

Merlino S, Orlandi P (2001) Carraraite and zaccagnaite, two new minerals from the Carrara marble quarries: their chemical compositions, physical properties, and structural features. Am Mineral $86: 1293-1301$

Moresi M, Mongelli G (1988) Underlying limestones and dolostones in Apulia, Italy. Clay Minerals 23:439-446

Newman ACD (1987) Chemistry of clays and clay minerals. Wiley, New-York

Reichert J, Borg G (2008) Numerical simulation and a geochemical model of supergene carbonatehosted non-sulphide zinc deposits. Ore Geol Rev 33:134-151. doi: 10.1016/j.oregeorev.2007.02.006 
Reynolds RCJ (1985) NEWMOD a computer program for the calculation of one-dimensional X-Ray diffraction patterns of mixed-layered clays. Reynolds, R C J, 8 Brook Dr., Hanover, New Hampshire

Robert J-L, Gasperin M (1985) Crystal structure refinement of hendricksite, a Zn- and Mn-rich trioctahedral, potassium mica: a contribution to the crystal chemistry of zinc-bearing minerals. Tschermaks Minerale Petrograph Mitteil 34:1-14

Ross CS (1946) Sauconite - a clay mineral of the montmorillonite group. Amer. Miner., 31: 411. Am Mineral 31:411-424

Ruaya JR, Seward TM (1986) The stability of chlorozinc(II) complexes in hydrothermal solutions up to $350^{\circ}$ C. Geoch Cosmoch Acta 50:651-661. doi: 10.1016/0016-7037(86)90343-1

Rule AC, Radke F (1988) Baileychlore, the Zn end member of the trioctahedral chlorite series. Am Mineral 73:135-139

Teixell A, Arboleya M-L, Julivert M, Charroud M (2003) Tectonic shortening and topography in the central High Atlas (Morocco). Tectonics 22:1051. doi: 10.1029/2002TC001460

Terracciano R (2008) Willemite Mineralisation in Namibia and Zambia. Dissertation, Università degli Studi di Napoli Federico II

Tiller KG, Pickering JG (1974) The Synthesis of Zinc Silicates at $20^{\circ} \mathrm{C}$ and Atmospheric Pressure. Clays and Clay Minerals 22:409-416. doi: 10.1346/CCMN.1974.0220507

Warme JE (1988) Jurassic carbonate facies of the Central and Eastern High Atlas rift, Morocco. In: Jacobshagen PDVH (ed) The Atlas System of Morocco. Springer Berlin Heidelberg, pp 169-199

Will P, Friedrich F, Hochleitner R, Gilg HA (2014) Fraipontite in the hydrothermally overprinted oxidation zone of the Preguiça mine, Southern Portugal. Mid-European Clay Conference, Dresde. 
801 Young B, Livingstone A, Thomson N (1992) Fraipontite from Wensleydale, North Yorkshire. Proc $802 \quad$ Yorkshire Geol Soc 49:125-127. doi: 10.1144/pygs.49.2.125 


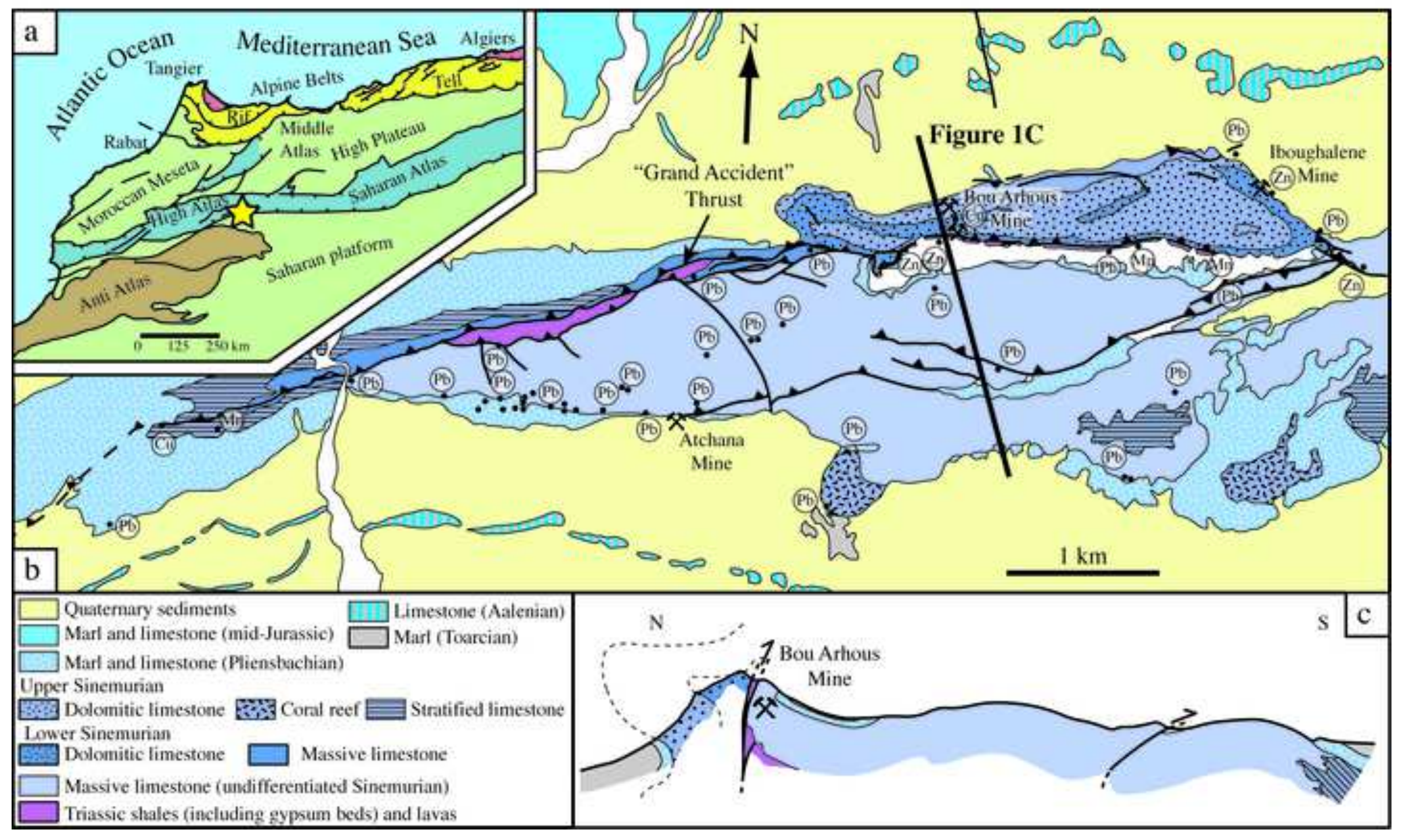




\section{Figure 2}

Click here to download Figure: Fig2.tif
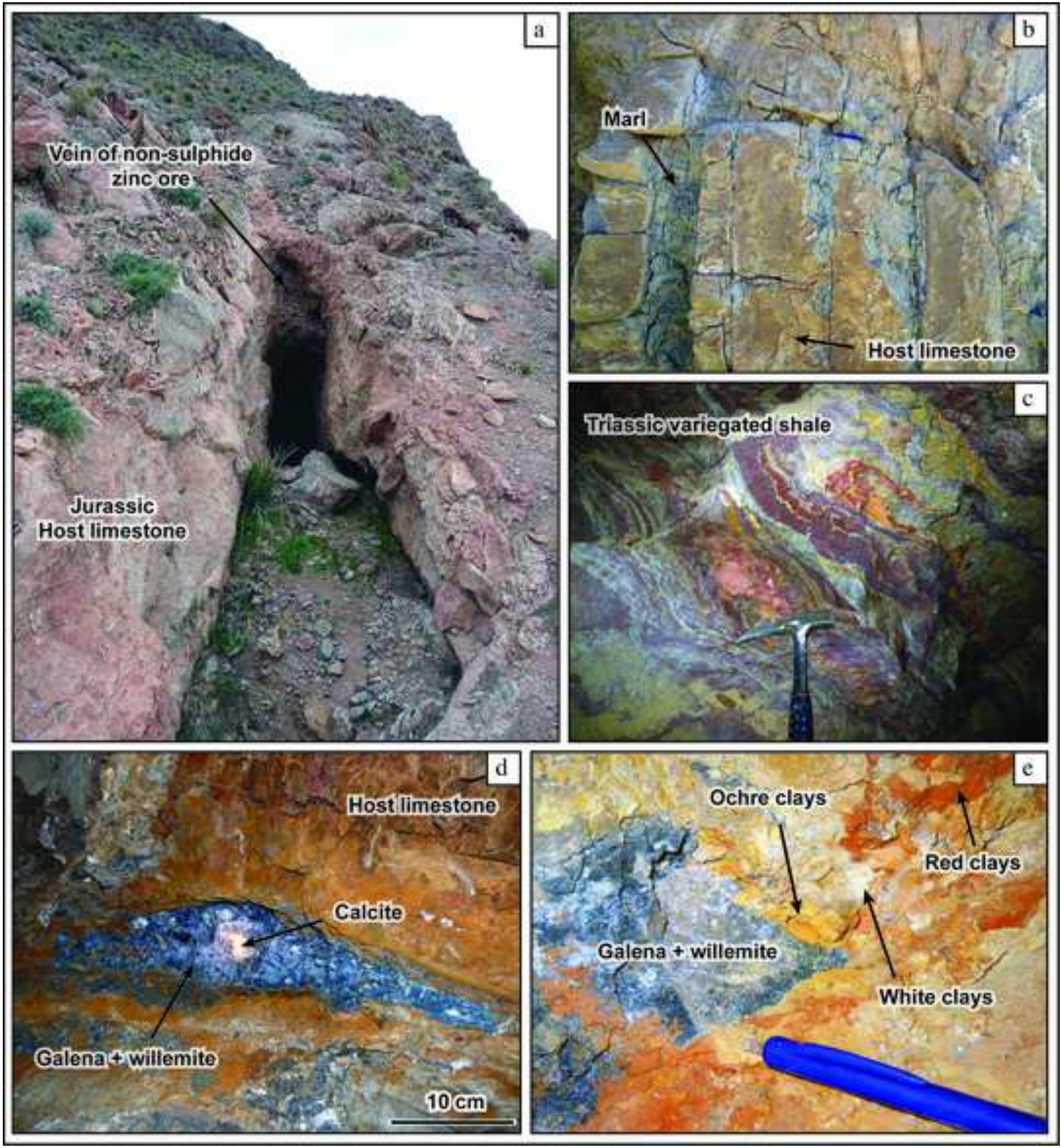


\section{Figure 3}

Click here to download Figure: Fig3.tif

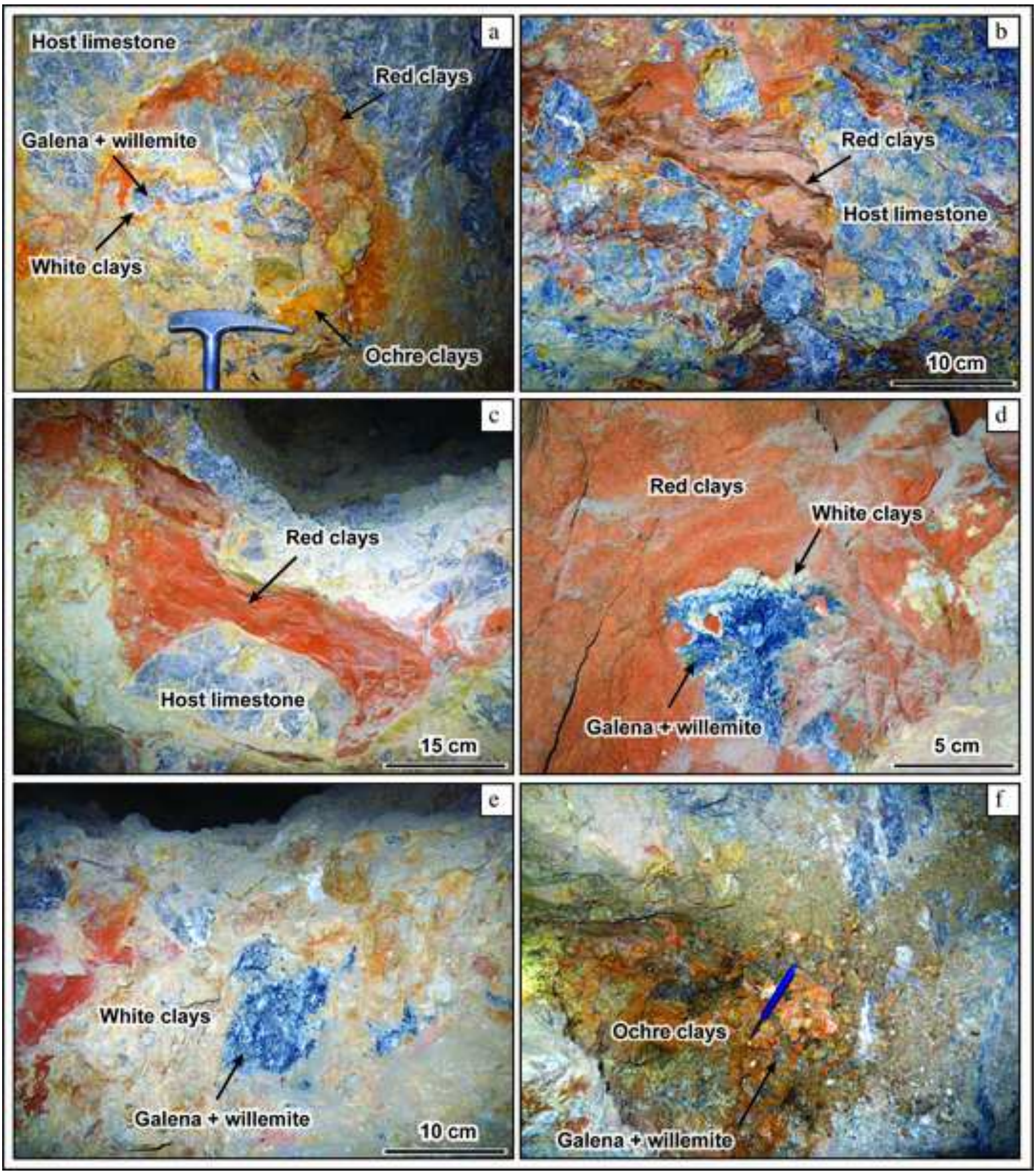




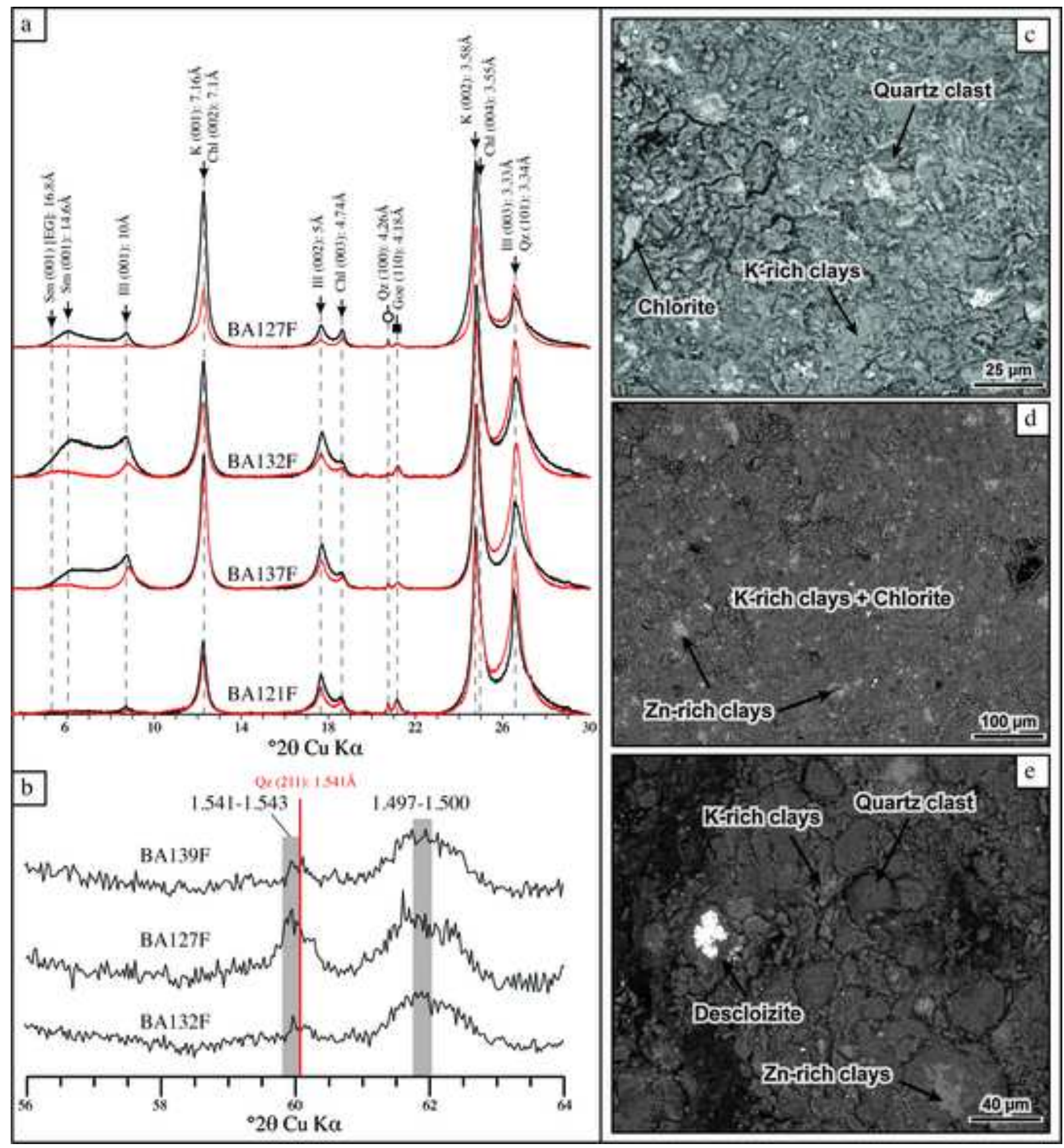




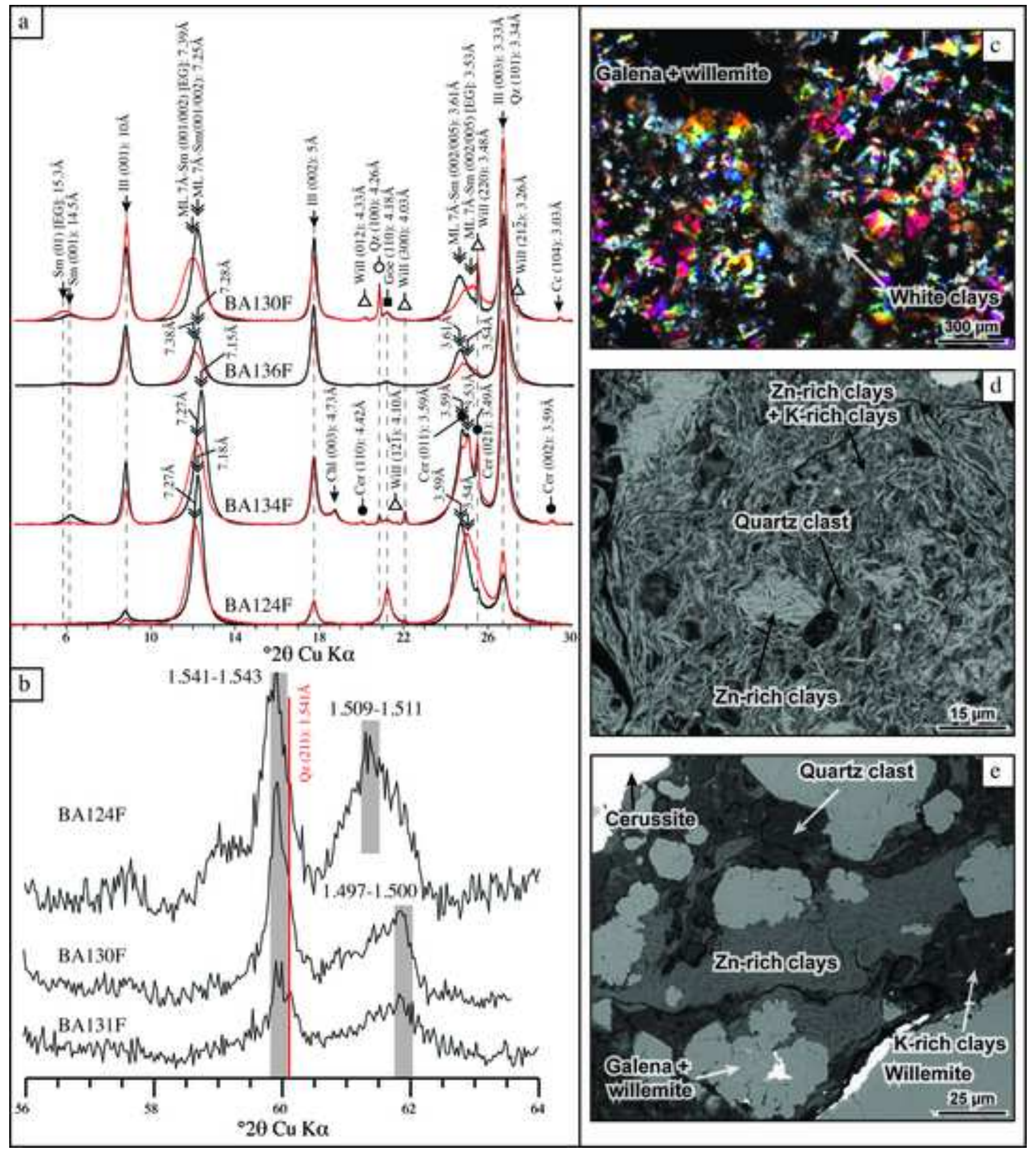




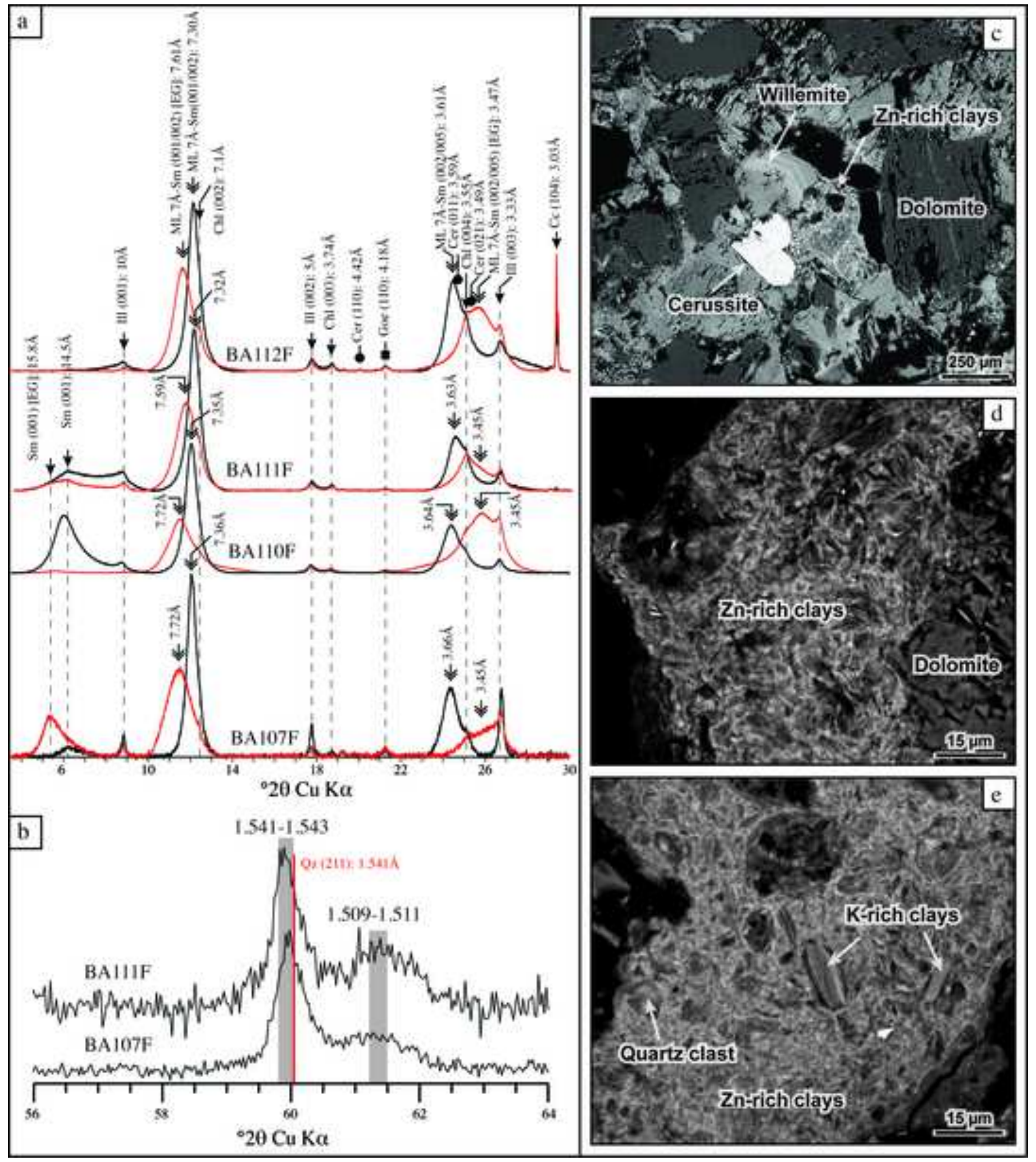



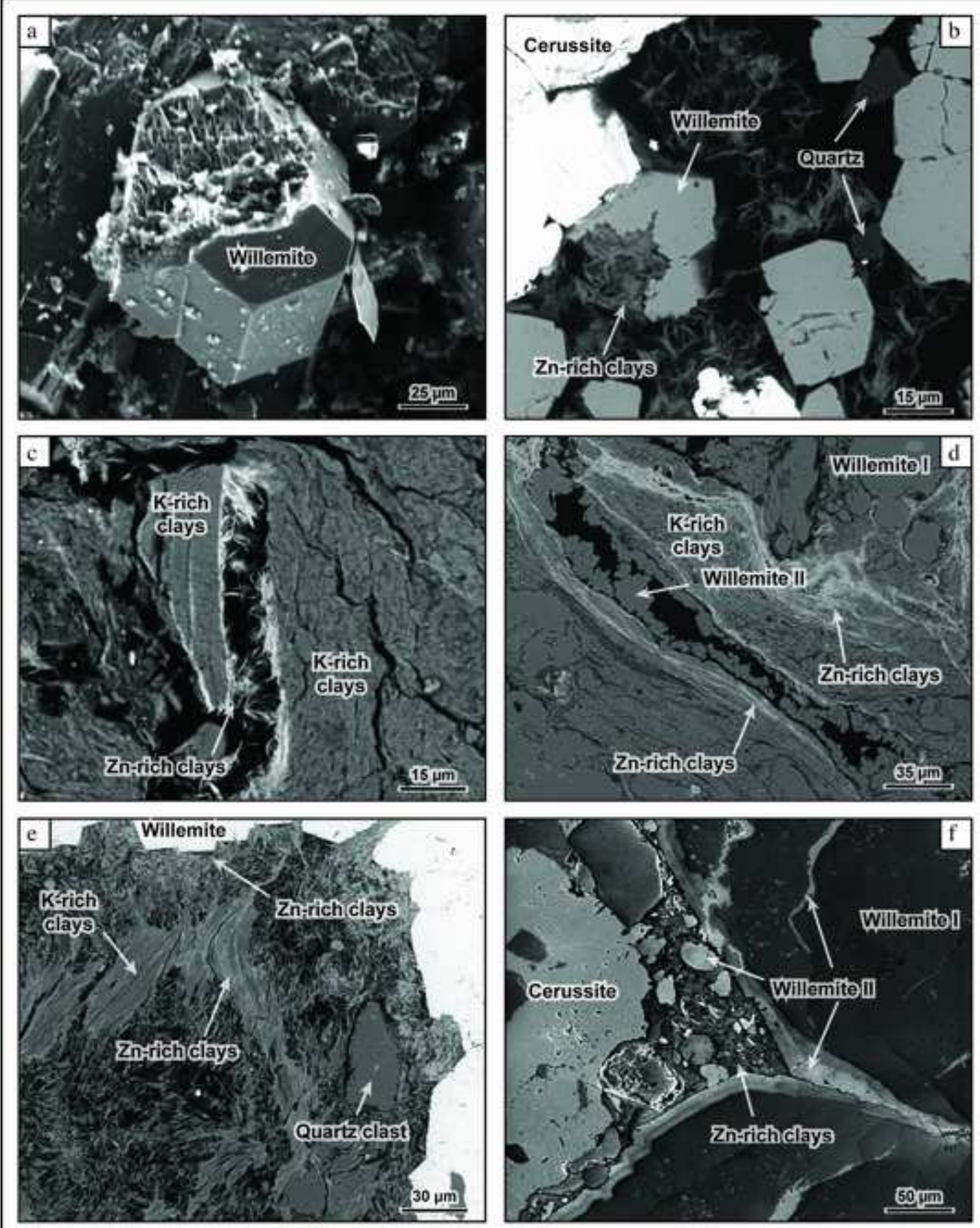


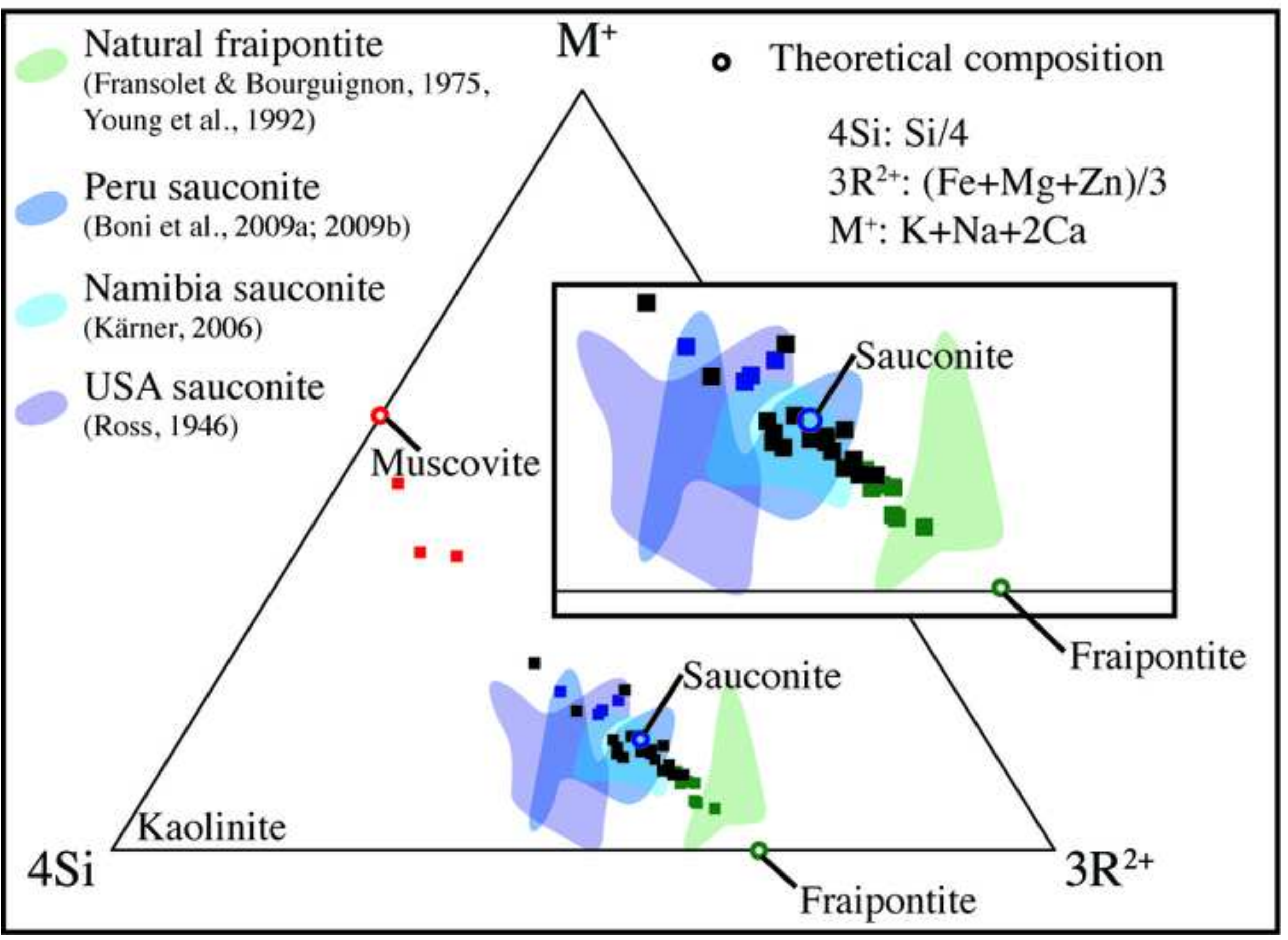




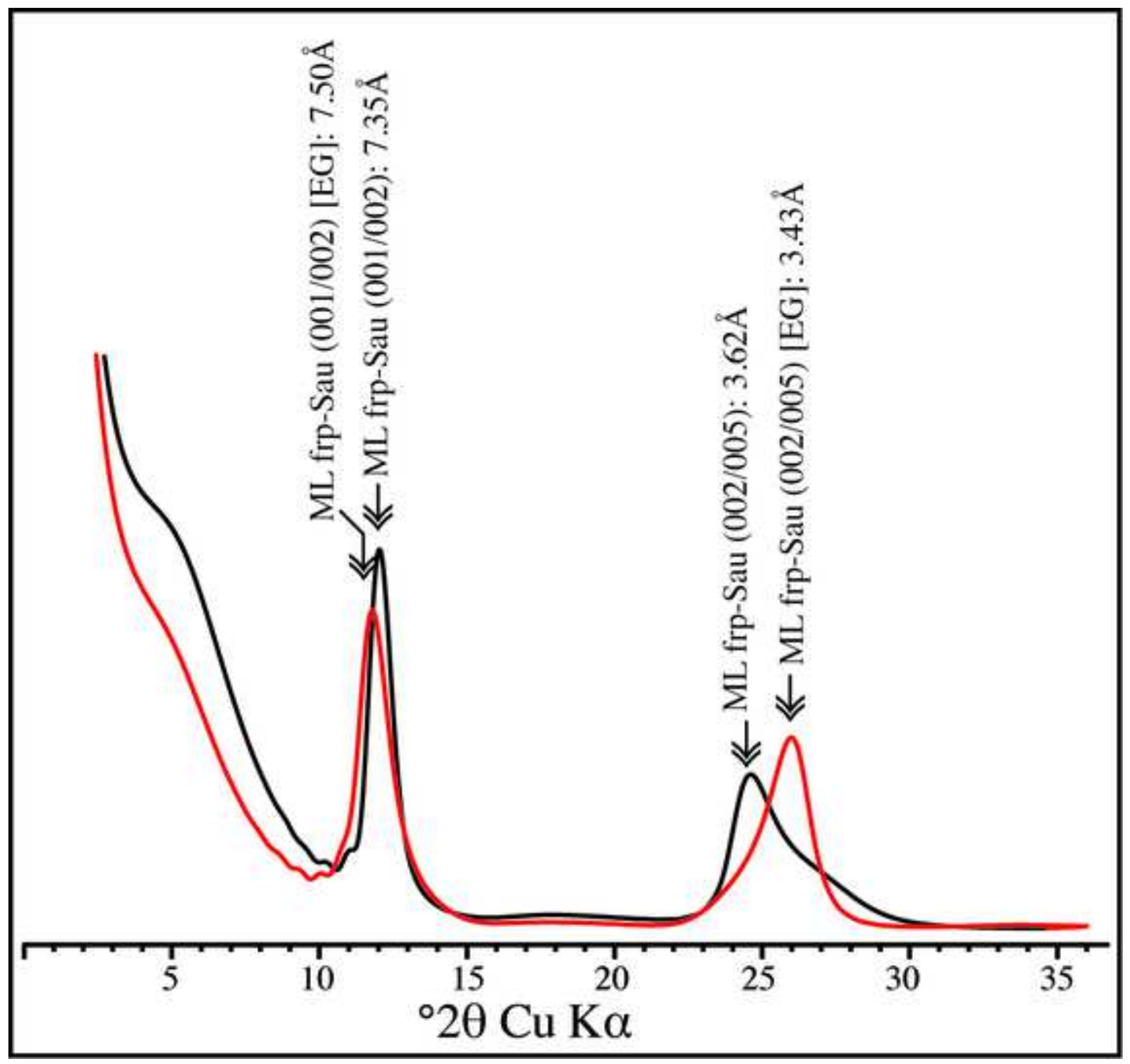




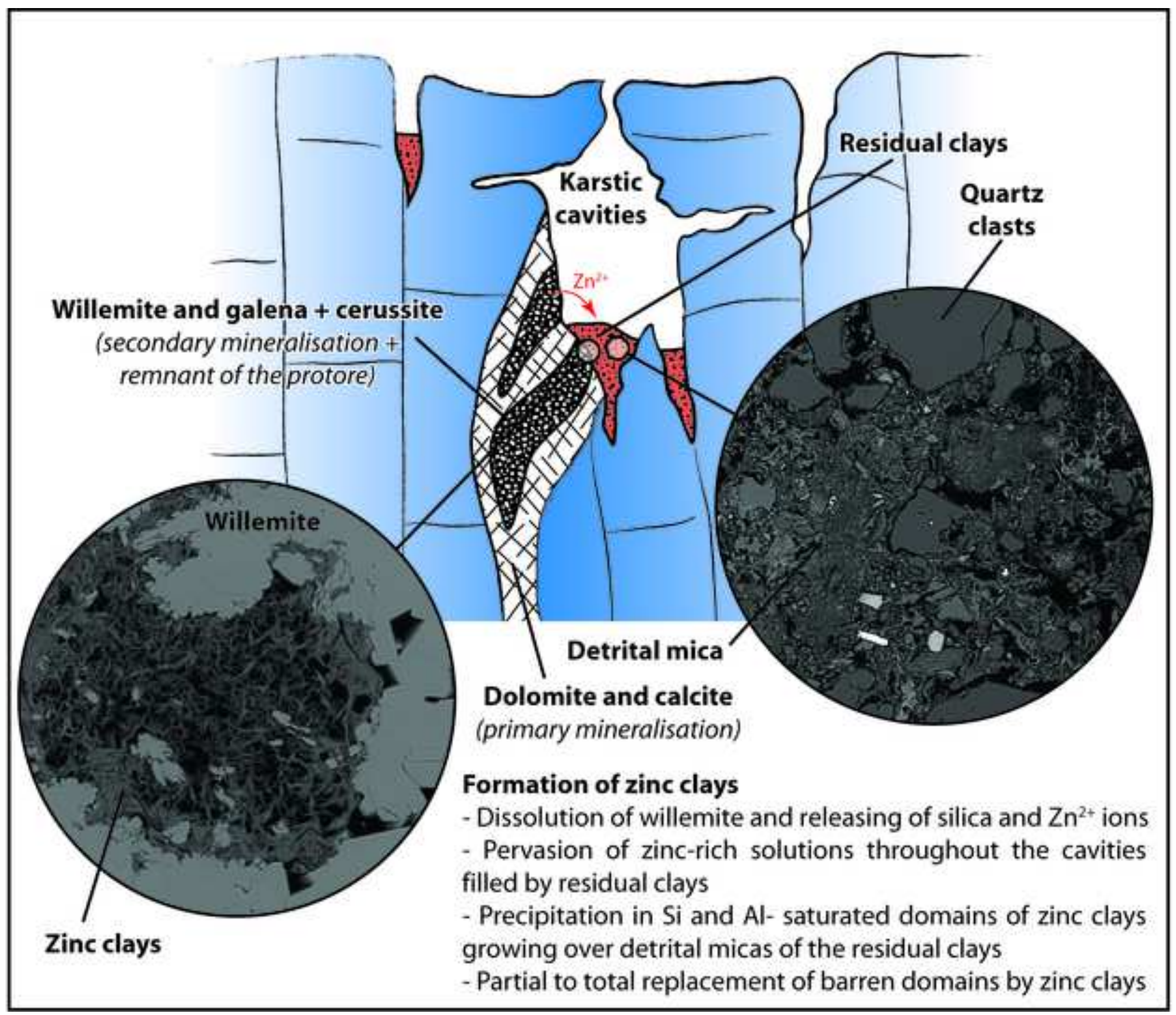




\begin{tabular}{|c|c|c|c|c|c|c|c|c|c|c|c|c|c|c|c|c|c|c|c|c|c|c|}
\hline Type & Sample & Mineralogy & LOI (\%) & $\mathrm{SiO2}(\%)$ & A12O3 (\%) & $\mathrm{Fe} 2 \mathrm{O} 3(\%)$ & $\mathrm{MgO}(\%)$ & ) $\mathrm{CaO}(\%)$ & $\mathrm{Na}(\%)$ & K2O (\%) & $\mathrm{MnO}(\%)$ & TiO2 $(\%)$ & P205 (\%) & As (ppm) & $\mathrm{Ba}(\mathrm{ppm})$ & $\operatorname{Cr}(\mathrm{ppm})$ & $\mathrm{Cu}(\mathrm{ppm})$ & $\mathrm{Ni}(\mathrm{ppm})$ & $\mathrm{Pb}(\mathrm{ppm})$ & $\mathrm{Sn}(\mathrm{ppm})$ & $\operatorname{Sr}(\mathrm{ppm})$ & ) Zn (ppm) \\
\hline \multicolumn{23}{|c|}{ Triassic clays } \\
\hline & BA125 & $\mathrm{qtz}, \mathrm{cl}, \mathrm{do}, \mathrm{cc}$ & 20.98 & 31.83 & 8.73 & 4.53 & 8.83 & 19.33 & 0.14 & 0.94 & 0.08 & 0.57 & 0.15 & 119 & 115 & 49 & 60 & 50 & 90 & 160 & 51 & 1409 \\
\hline & BA139 & $q t z, c c, c l, g o e$ & 19.44 & 29.13 & 10.1 & 8.33 & 0.71 & 20.91 & 0.12 & 2.85 & 0.05 & 0.5 & 0.71 & 2177 & 71 & 163 & 293 & 85 & 27400 & 84 & 116 & 27600 \\
\hline & BA141 & do, qtz, cl, cc, goe & & & & & & & & & & & & & & & & & & & & \\
\hline & BA142 & $\mathrm{cl}, \mathrm{qtz}$, goe, he, cc & 6.04 & 45.3 & 14.1 & 24.57 & 1 & 0.81 & 0.1 & 4.38 & 0.06 & 0.73 & 0.31 & 726 & 136 & 70 & 166 & 28 & 9520 & 106 & 40 & 9672 \\
\hline & BA143 & $\mathrm{qtz}, \mathrm{cl}$, he, do & 6.1 & 59.98 & 12.15 & 8.12 & 7.58 & 1.07 & 0.0861 & 1.8 & 0.02 & 0.86 & 0.14 & 98 & 232 & 75 & 98 & 49 & 453 & 146 & 30 & 15000 \\
\hline & BA144 & $\mathrm{qtz}, \mathrm{do}, \mathrm{cl}$ & 13.6 & 45.66 & 11.58 & 6.2 & 11.92 & 6.34 & 0.0968 & 1.34 & 0.09 & 0.77 & 0.16 & 72 & 349 & 59 & 169 & 49 & 1020 & 152 & 34 & 19300 \\
\hline & BA149 & $q z, g y, c l$ & 9.23 & 46.87 & 11.45 & 5.82 & 9.57 & 8.58 & - & 1.18 & 0.01 & 0.72 & 0.18 & 92 & 277 & 85 & 26 & 49 & 48 & 101 & 376 & 60 \\
\hline \multicolumn{23}{|c|}{ Jurassic rocks } \\
\hline & BA147 & $\mathrm{qtz}, \mathrm{cc}, \mathrm{cl}, \mathrm{do}$ & 20.22 & 37.15 & 10.94 & 5.52 & 3.96 & 16.89 & 0.31 & 2.95 & 0.05 & 0.59 & 0.15 & 194 & 372 & 41 & 59 & 40 & 115 & 207 & 225 & 301 \\
\hline & BA148 & $\mathrm{cc}, \mathrm{do}, \mathrm{cl}, \mathrm{qtz}$ & 34.68 & 17.19 & 1.94 & 1.92 & 1.04 & 40.88 & 0.0758 & 0.35 & 0.09 & 0.11 & 0.09 & 86 & 110 & 17 & 83 & 27 & 80 & 158 & 419 & 186 \\
\hline & & & 34.8 & 17.18 & 2.06 & 1.93 & 1.08 & 40.43 & 0.0765 & 0.38 & 0.09 & 0.1 & 0.1 & 64 & 131 & 15 & 83 & 31 & 79 & 159 & 433 & 197 \\
\hline & BA148bis & $\mathrm{cc}, \mathrm{qtz}, \mathrm{cl}$ & & & & & & & & & & & & & & & & & & & & \\
\hline & BA150 & $\mathrm{cc}, \mathrm{cl}, \mathrm{do}, \mathrm{qtz}$ & 41.76 & 3.79 & 0.92 & 1.73 & 6.11 & 43.91 & - & nd & 0.18 & 0.09 & 0.04 & 109 & 100 & 14 & 43 & nd & 148 & 100 & 83 & 392 \\
\hline & BA151 & $\mathrm{cc}, \mathrm{do}, \mathrm{cl}, \mathrm{qtz}$ & & & & & & & & & & & & & & & & & & & & \\
\hline & BA152 & $\mathrm{do}, \mathrm{cc}, \mathrm{cl}, \mathrm{qtz}$ & & & & & & & & & & & & & & & & & & & & \\
\hline & BA153 & do, ce, qtz, cl, do, ga & 27.06 & 14.8 & 2.29 & 0.94 & 2.46 & 25.86 & - & 0.13 & 0.05 & 0.16 & 0.11 & 306 & 108 & 31 & 218 & nd & 221200 & 66 & 219 & 25700 \\
\hline & BA154 & $q t z, c c, c l$ & & & & & & & & & & & & & & & & & & & & \\
\hline & BA156 & $\mathrm{do}, \mathrm{cc}, \mathrm{cl}, \mathrm{qtz}$ & 43.86 & 2.37 & 1.17 & 1.32 & 13.13 & 36.6 & - & 0.21 & 0.1 & 0.08 & 0.06 & 118 & 10 & 16 & 23 & nd & 941 & 80 & 145 & 2588 \\
\hline & BA157 & $\mathrm{cc}, \mathrm{qtz}, \mathrm{cl}$ & 25.15 & 29.56 & 7.82 & 3.07 & $\mathrm{~h}$ & 27.7 & - & 1.98 & 0.04 & 0.5 & 0.12 & 159 & 105 & 39 & 98 & 40 & 157 & 147 & 299 & 214 \\
\hline & BA158 & $\mathrm{do}, \mathrm{cc}, \mathrm{cl}$ & 44.94 & 0.51 & 0.3 & 1.95 & 11.94 & 37.94 & - & nd & 0.14 & 0.02 & 0.07 & 109 & 70 & 11 & 52 & nd & 145 & 153 & 53 & 381 \\
\hline & BA159 & do, cc, qtz, cl & 37.13 & 10.01 & 4.97 & 2.19 & 6.71 & 35.78 & - & 1.1 & 0.34 & 0.29 & 0.14 & 34 & 424 & 29 & 37 & 54 & 919 & 142 & 83 & 403 \\
\hline & BA160 & cc, gtz, cl goe & 26.41 & 30.36 & 5.27 & 6.5 & 0.44 & 28 & - & 1.01 & 0.09 & 0.4 & 0.16 & 141 & 79 & 38 & 97 & nd & 1400 & 111 & 118 & 919 \\
\hline & & & 26.43 & 30.25 & 5.34 & 6.69 & 0.44 & 27.9 & - & 0.98 & 0.09 & 0.42 & 0.17 & 181 & 83 & 39 & 103 & 38 & 1349 & 115 & 120 & 937 \\
\hline \multicolumn{23}{|c|}{ Red clays } \\
\hline & BA101 & $q t z, c c, c l$ & 15.25 & 50.62 & 6.31 & 3.43 & 0.33 & 16.54 & 0.15 & 0.57 & 0.06 & 0.85 & 0.17 & 82 & 93 & 61 & 261 & 214 & 526 & 120 & 91 & 830 \\
\hline & BA113 & $q t z, c l, d o$ & 3.89 & 77.06 & 7.78 & 5.57 & 0.83 & 0.97 & 0.11 & 0.84 & 0.1 & 0.8 & 0.1 & 83 & 126 & 61 & 114 & 72 & 753 & 142 & 40 & 3495 \\
\hline & BA115 & $q t z, c l$ & 7.9 & 50.68 & 20.49 & 8.87 & 1.79 & 0.64 & 0.16 & 2.53 & 0.06 & 1.17 & 0.15 & 469 & 361 & 112 & 173 & 65 & 1657 & 46 & 110 & 8495 \\
\hline & BA116 & $\mathrm{qtz}, \mathrm{cl}, \mathrm{cc}$ & & & & & & & & & & & & & & & & & & & & \\
\hline & BA121 & $\mathrm{qtz}, \mathrm{cl}$, goe & 7.62 & 52.99 & 18.99 & 10.02 & 1.75 & 0.5 & 0.11 & 2.35 & 0.03 & 1.15 & 0.2 & 327 & 228 & 89 & 159 & 36 & 1732 & 51 & 96 & 30000 \\
\hline & BA126 & $\mathrm{qtz}, \mathrm{cc}, \mathrm{cl}$ & 7.15 & 73.49 & 3.38 & 1.79 & 0.17 & 7.95 & 0.1 & 0.31 & 0.05 & 0.45 & 0.1 & 274 & 488 & 40 & 98 & 42 & 1869 & 142 & 37 & 9352 \\
\hline & BA127 & $q t z, c c, c l$ & 8.76 & 49.62 & 18.42 & 7.19 & 2.17 & 2.07 & 0.12 & 1.87 & 0.02 & 1.04 & 0.13 & 149 & 308 & 86 & 179 & 84 & 1214 & 88 & 115 & 47300 \\
\hline & BA132 & $\mathrm{qtz}, \mathrm{cl}, \mathrm{cc}$ & & & & & & & & & & & & & & & & & & & & \\
\hline & BA137 & $\mathrm{qtz}, \mathrm{cl}, \mathrm{cc}, \mathrm{ce}$ & 8.21 & 62.24 & 14.48 & 6.1 & 1.44 & 3.57 & 0.0881 & 1.76 & 0.03 & 0.98 & 0.1 & 101 & 195 & 78 & 109 & 43 & 1097 & 140 & 76 & 6362 \\
\hline \multicolumn{23}{|c|}{ White $\mathrm{Cla}$} \\
\hline & BA117 & will, ce, cc, cl, qtz, do, ga & & & & & & & & & & & & & & & & & & & & \\
\hline & BA118 & ce, will, cl, qtz, cc, ga, do & & & & & & & & & & & & & & & & & & & & \\
\hline & BA124 & will, cl, ce, goe, qtz, cc & 15.66 & 18.21 & 1.78 & 3.24 & LD & 20.89 & 0.0778 & 0.25 & 0.03 & 0.1 & 0.33 & 459 & 49 & 43 & 193 & 56 & 8094 & 210 & 47 & 322400 \\
\hline & BA128 & will, cl, ce, ga & & & & & & & & & & & & & & & & & & & & \\
\hline & BA130 & $q t z$, will, cl, cc, do & 9.13 & 47.32 & 5.36 & 2.08 & 0.92 & 8.32 & 0.21 & 1.17 & 0.02 & 0.34 & 0.24 & 1133 & 176 & 138 & 255 & 34 & 9218 & 101 & 53 & 180900 \\
\hline & BA131 & $\mathrm{qtz}, \mathrm{cc}, \mathrm{cl}$, will, do & & & & & & & & & & & & & & & & & & & & \\
\hline & BA133 & will, $\mathrm{qt}, \mathrm{cl}, \mathrm{do}, \mathrm{cc}$ & & & & & & & & & & & & & & & & & & & & \\
\hline & BA134 & will, ce, qtz, cl, ga & & & & & & & & & & & & & & & & & & & & \\
\hline & BA135 & will, cl, cc, qtz, ce, ga, goe & & & & & & & & & & & & & & & & & & & & \\
\hline & BA136 & $\mathrm{qtz}, \mathrm{cl}, \mathrm{do}$, will, ce & 25.86 & 29.94 & 6.95 & 1.43 & 10.36 & 16.97 & 0.0926 & 1.88 & 0.16 & 0.36 & 0.17 & 411 & 46 & 69 & 127 & 36 & 37100 & 138 & 237 & 17400 \\
\hline & BA138 & will, cl,ce, qtz, ga & & & & & & & & & & & & & & & & & & & & \\
\hline & BA145 & do, ce, cl, qtz, ga & & & & & & & & & & & & & & & & & & & & \\
\hline \multicolumn{23}{|c|}{ Ocher clays } \\
\hline & BA102 & $\mathrm{qtz}, \mathrm{do}, \mathrm{cl}$, dol & 9.65 & 47.09 & 17.89 & 10.41 & 3.41 & 4.01 & 0.18 & 2.32 & 0.12 & 1.13 & 0.09 & 574 & 451 & 140 & 10848 & 117 & 3202 & 137 & 73 & 7748 \\
\hline & BA103 & do, cc, cl, qtz & & & & & & & & & & & & & & & & & & & & \\
\hline & BA104 & $\mathrm{cc}, \mathrm{cl}, \mathrm{do}, \mathrm{qtz}$ & 15.57 & 31.13 & 14.94 & 7.99 & 2.96 & 11.46 & 0.18 & 1.87 & 0.18 & 1.14 & 0.11 & 586 & 8530 & 85 & 223 & 125 & 3321 & 182 & 161 & 64600 \\
\hline & BA107 & $\mathrm{cl}, \mathrm{cc}, \mathrm{do}, \mathrm{qtz}$ & 14.02 & 26.12 & 9.6 & 7.93 & 2.66 & 7.58 & 0.14 & 0.85 & 0.12 & 0.71 & 0.11 & 389 & 84 & 58 & 401 & 180 & 1384 & 131 & 70 & 237000 \\
\hline & BA108 & $\mathrm{qtz}, \mathrm{cc}, \mathrm{cl}, \mathrm{do}$ & 17.56 & 32.67 & 7.56 & 15.2 & 3.75 & 15.86 & 0.15 & 1.23 & 0.1 & 0.44 & 0.19 & 590 & 240 & 103 & 488 & 73 & 4273 & 72 & 68 & 27600 \\
\hline & BA110 & do, cl, qtz, cc, ce & 26.66 & 16.49 & 5.45 & 2.29 & 1.8 & 29.3 & 0.2 & 0.5 & 0.07 & 0.31 & 0.09 & 146 & 49 & 41 & 564 & 154 & 27100 & 149 & 135 & 92000 \\
\hline & BA111 & $\mathrm{cl}, \mathrm{do}, \mathrm{cc}, \mathrm{qtz}$ & & & & & & & & & & & & & & & & & & & & \\
\hline & BA112 & $\mathrm{cc}, \mathrm{cl}$, do, qtz & & & & & & & & & & & & & & & & & & & & \\
\hline & BA114 & $\mathrm{qtz}, \mathrm{cl}, \mathrm{do}, \mathrm{cc}$ & 7.64 & 59.21 & 18.52 & 4.69 & 1.36 & 0.68 & 0.16 & 1.75 & 0.04 & 1.38 & 0.13 & 88 & 237 & 114 & 135 & 66 & 949 & 57 & 111 & 21500 \\
\hline & BA119 & $\mathrm{cc}, \mathrm{cl}, \mathrm{ce}, \mathrm{qtz}, \mathrm{do}$ & 39.26 & 5.45 & 2.67 & 1 & 0.76 & 43.52 & 0.13 & 0.66 & 0.05 & 0.16 & 0.1 & 271 & 31 & 32 & 73 & 36 & 19440 & 51 & 315 & 6275 \\
\hline & BA123 & $\mathrm{qtz}, \mathrm{cl}, \mathrm{cc}, \mathrm{do}$ & 8.59 & 53.29 & 20.17 & 7.88 & 1.95 & 1.73 & 0.14 & 2.21 & 0.08 & 1.1 & 0.14 & 195 & 263 & 100 & 100 & 48 & 2394 & 70 & 102 & 18400 \\
\hline & BA146 & $\mathrm{qtz}, \mathrm{do}, \mathrm{cl}, \mathrm{cc}$ & 20 & 37.98 & 12.29 & 2.11 & 7.45 & 11.31 & 0.11 & 3.13 & 0.05 & 0.69 & 0.16 & 137 & 269 & 54 & 40 & 26 & 1598 & 161 & 58 & 7408 \\
\hline
\end{tabular}




\begin{tabular}{|c|c|c|c|c|}
\hline Type & Clay content & Sample & $\operatorname{CEC}(\mathrm{meq} / 100 \mathrm{~g})$ & {$[\mathrm{Zn}](\%)$ of the CEC } \\
\hline \multirow[t]{4}{*}{ Red Clays } & kaol > ill >> chl & BA121 & 34 & 40.873 \\
\hline & kaol >> ill $(M L$ ill/sm $)>$ chl & BA127 & 30 & 0.235 \\
\hline & kaol > ill (IS ill/sm) $>>$ chl & BA132 & 35 & 0.167 \\
\hline & kaol > ill (IS ill/sm) $>>$ chl & BA137 & 38 & 0.047 \\
\hline \multirow[t]{5}{*}{ White Clays } & White Clays & & & \\
\hline & $\mathrm{ML}(7 \AA \AA A s m)>>$ ill & BA124 & 13 & 1.555 \\
\hline & ill $>M L(7 \AA ̊ s m)>>s m$ & BA130 & 12 & 0.168 \\
\hline & $\mathrm{ML}(7 \AA / \mathrm{sm})>$ ill $>>\mathrm{chl}>\mathrm{sm}$ (not presented) & BA131 & 27 & 0.121 \\
\hline & ill > ML $(7 \AA ̊ s m)$ & BA136 & 9 & 0.486 \\
\hline \multirow[t]{5}{*}{ Ocher Clays } & Ocher Clays & & & \\
\hline & $\mathrm{ML}(7 \AA / \mathrm{sm})>\mathrm{sm}>>$ ill & BA107 & 41 & 0.055 \\
\hline & $\mathrm{ML}(7 \AA / \mathrm{sm})>$ ill $>>$ sm $($ not presented $)$ & BA108 & 19 & 0.000 \\
\hline & $\mathrm{ML}(7 \AA / s m)>\mathrm{sm}>>$ ill $>\mathrm{chl}$ & BA110 & 40 & 0.046 \\
\hline & $\mathrm{ML}(7 \AA / \mathrm{sm})>>$ sm $>$ ill $>$ chl & BA111 & 34 & 0.594 \\
\hline
\end{tabular}




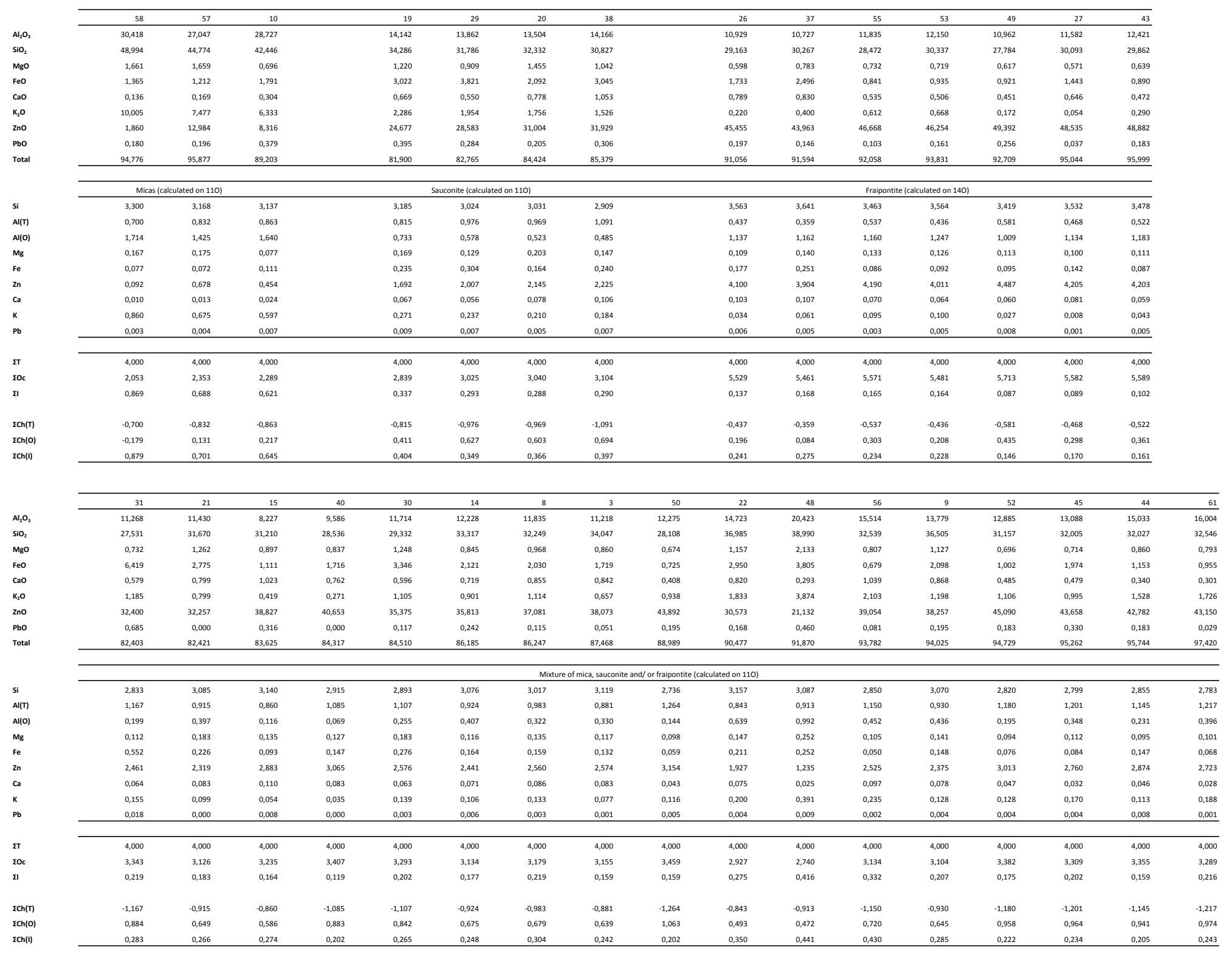

